(-) institute of development studies

Working Paper

Volume 2020 Number 542

\title{
Beyond Informal Social \\ Protection - Personal \\ Networks of Economic \\ Support in Namibia
}

Annalena Oppel

November 2020 
The Institute of Development Studies (IDS) delivers world-class research, learning and teaching that transforms the knowledge, action and leadership needed for more equitable and sustainable development globally.

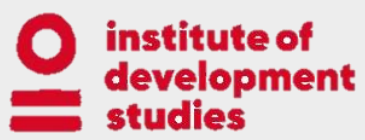

(C) Institute of Development Studies 2020

Working Paper Volume 2020 Number 542

Beyond Informal Social Protection - Personal Networks of Economic Support in Namibia

Annalena Oppel

November 2020

First published by the Institute of Development Studies in November 2020

ISSN: 2040-0209 ISBN: 978-1-78118-721-0

DOI: $10.19088 /$ IDS.2020.002

A catalogue record for this publication is available from the British Library

This research was funded by the German Foundation of Business (Stiftung der Deutschen Wirtschaft) through a grant provided for doctoral studies and Institute of Development Studies.

(C) Institute of Development Studies 2020. This is an Open Access paper distributed under the terms of the Creative Commons Attribution Non Commercial 4.0 International licence (CC BY-NC), which permits use, distribution and reproduction in any medium, provided the original authors and source are credited, any modifications or adaptations are indicated, and the work is not used for commercial purposes.

Available from:

Institute of Development Studies, Library Road

Brighton, BN1 9RE, United Kingdom

+44 (0)1273915637

ids.ac.uk

IDS is a charitable company limited by guarantee and registered in England

Charity Registration Number 306371

Charitable Company Number 877338 
Working Paper

Volume 2020 Number 542

\section{Beyond Informal Social \\ Protection - Personal \\ Networks of Economic \\ Support in Namibia}

Annalena Oppel

November 2020 


\title{
Beyond Informal Social Protection - Personal Networks of Economic Support in Namibia
}

\author{
Annalena Oppel \\ November 2020
}

\section{Summary}

This paper poses a different lens on informal social protection (ISP). ISP is generally understood as practices of livelihood support among individuals. While studies have explored the social dynamics of such, they rarely do so beyond the conceptual space of informalities and poverty. For instance, they discuss aspects of inclusion, incentives and disincentives, efficiency and adequacy. This provides important insights on whether and to what extent these practices provide livelihood support and for whom. However, doing so in part disregards the sociopolitical context within which support practices take place. I therefore introduce the lens of between-group inequality through the Black Tax narrative. I draw on unique mixed method data of 205 personal support networks of Namibian adults. My results show how understanding these practices beyond the lens of informal social protection can provide important insights on how economic inequality resonates in support relationships, which in turn can play a part in reproducing the inequalities to which they respond.

\section{Keywords}

Informal social protection; inequality; personal networks; mixed methods; Namibia.

\section{Authors}

Annalena Oppel is a doctoral candidate at the Institute of Development Studies, UK. Her main research focuses on how inequalities are (re-)produced in everyday practices and interactions by applying novel mixed methods approaches to network studies. Annalena is currently a postdoctoral research associate at the UNU-WIDER research institute. Previously, she was a visiting scholar at the Department of Sociology at Harvard University and gained research experience at the University of Sussex, London School of Economics as well as working for the German Development Cooperation GIZ and OECD. Any views expressed in this article are exclusively her own and do not necessarily reflect those of the institutions with which the author is affiliated. 


\section{Executive Summary}

This paper explores support practices to revisit understandings of informal social protection (ISP). The latter generally refers to support provided among individuals which was found to play an important role for individuals' welfare in the global South; particularly if formal welfare provisioning leaves important coverage gaps. ISP thus describes support practices within networks of community, kinship, or family members. A multitude of studies explored their internal, social dynamics, i.e. they describe aspects of problematic inclusion and dependencies, but also to what extent these social systems can respond to external shocks or function as mutual insurance.

While they provide valuable insights, understandings are often generated within confined spaces, i.e. rural or poor communities. Further, rationales to describe support practices resemble those of formal policymaking. Doing so puts less weight on the socio-political context and further extracts support from its social relationships. I thus reposition the lens by first, accounting for between-group inequalities and second, by centring individuals' meaning of support within relationships. I revisit internal dynamics by exploring mixed-method data containing 205 personal networks of support of adult Namibians. Using network measures and thematic analysis, I compare different support dynamics across white and non-white ethnic identity groups to reflect Namibia's former apartheid regime and continued economic inequality.

My results show that network compositions differ across ethnic inequalities. This includes a greater regularity of support activities observed in the networks of non-white individuals. Further, more peer-to-peer support takes place among higher education levels for white individuals while respective support of nonwhite individuals was linked to lower educated or unemployed individuals. In addition, non-white individuals' personal motives and intentions depicted a stronger sense of necessity, dependency and responding to external challenges such as unemployment, poverty, lack of capability to cater for basic needs. This also resembles the narrative of Black Tax, whereby having studied or having a job necessitates taking care of those who economically fare worse.

An exploration of personal motives and intentions also revealed individuals' obstacles and circumstances they face, the opportunities they have or foresee for someone, as well as how they make sense of, tackle or utilise them. I therefore discuss the aspect of 'compatibility' as well as 'support as necessity' to think beyond framings of ISP; particularly illustrating how understanding these practices across socio-economic strata and varying degrees of necessity can provide new ways of understanding how ISP is placed in the larger society as a whole. 


\section{Contents}

Executive Summary

Acknowledgements

Acronyms

1. Introduction

2. Current understandings of informal social protection

3. Centring the Black Tax narrative

4. Data and definitions

4.1 Definition of support

4.2 Relevant data

5. Analytical strategy

5.1 Network measures

5.2 Thematic analysis

6. Compositions and structures of personal networks

6.1 General patterns of personal networks

6.2 Structural indicators across ethnic identity groups

7. Differing motives and intentions: support temporality

7.1 Regular support activities 
8.1 The compatibility aspect of the 'informal'

8.2 Support as a function of necessity

9. Conclusion 


\section{Tables}

Table 4.1 An economic welfare-based framework for social support

Table 4.2 Age, education, and labour status across ethnic identity groups

Table 6.1 Compositions across personal networks

Table 6.2 Ego-alter similarities in network composition

Table 6.3 Support temporality across ethnic identity groups

Table 6.4 Age composition across ethnic identity groups

Table 6.5 Ego-Alter similarity across ethnic identity groups

Table A1 Overview of the criteria considered when selecting the six ethnic identity groups included in this research

Table A2 Analytical steps applied for analysing regular support activities 


\section{Acknowledgements}

Thanks to Keetie Roelen and Stephen Devereux for their helpful inputs and suggestions. This research was funded by the German Foundation of Business (Stiftung der Deutschen Wirtschaft) through a grant provided for doctoral studies.

\section{Acronyms}

$\begin{array}{ll}\text { EI } & \text { External-Internal Index } \\ \text { IQR } & \text { Interquartile Range } \\ \text { ISCO } & \text { International Standard Classification of Occupations } \\ \text { ISP } & \text { Informal Social Protection } \\ \text { NAD } & \text { Namibian Dollar } \\ \text { NW } & \text { Non-White } \\ \text { SD } & \text { Standard Deviation } \\ \text { SE } & \text { Standard Error } \\ \text { TV } & \text { Television } \\ \text { W } & \text { White }\end{array}$




\section{Introduction}

Informal social protection (ISP) generally describes social mechanisms that function as livelihood support which is provided among members of a community. This framing is primarily found in studies which focus on contexts of the global South. Referred to as informal welfare, or informal safety nets, the underpinning social systems often remain understood through policy principles. This includes whether individual actions of support can measure up to or are efficiently placed alongside formal welfare provisioning (Cox and Fafchamps 2007; Heemskerk, Norton, and de Dehn 2004; Oduro 2010). Thereby, the 'inner workings' of such informal practices are typically explored in terms of their coverage, adequacy, efficiency or robustness (Arnall et al. 2004; Calder and Tanhchareun 2014; Di Falco and Bulte 2011; 2013; Werger 2009). Doing so puts socially embedded practices into the same conceptual space as the state and enables analyses which in part disregard the the socio-political context within which such support practices take place.

In this paper, I argue that not all actions are intended and governed with the foresight of co-crafting someone's socioeconomic position - a notion that is reflected in the formulation of welfare policies. Instead, activities range from adhoc gestures, daily habits, mutual favours, to long-term investments into someone else's future. Through understanding these activities, one gets a glimpse into the life trajectories of a person and their immediate contacts beyond the policy principles of whether actions are efficient, adequate, wellplanned or intended. Consequently, I intend to alter the approach of understanding two-directed interdependencies between individual distributive behaviour and socioeconomic context. It involves, to some extent, layering the field of vision. By this, I mean that I set out to balance a systemic view to capture social systems and patterns with a deeper understanding of individuals' meaning of economic support.

I thus reframe current understandings of ISP and deconstruct roles, functions and the impact of social support through centring the lived experience of adult Namibians speaking about their support practices and activities. I further set a focus on how these behaviours constitute networks and behavioural patterns within communities as well as re-drawing lines of inequalities - particularly horizontal inequalities across ethnic identities. By taking a socially embedded stance, this research thus takes a step beyond the framing of ISP. Thereby, it contributes to filling a gap in the literature on practices of support behaviour and their twofold interaction with the socio-political context of an urban society in the global South. 
I begin this paper by revisiting current understandings of ISP in the global South. I then introduce 'Black Tax' as being a colloquial term and narrative around the lived experience of economic support in Namibia. Thereby, I point out how applying this narrative as a conceptual lens can yield a different perspective on support practices. By drawing on primary, egocentric networks, I use a mixedmethods approach to provide insights on the structure and meaning of support. I further highlight patterns which correspond to Namibia's socio-political context and racial inequalities more specifically. I conclude by drawing out key arguments and suggestions regarding the current understanding and exploration of ISP beyond a policy framing. Particularly, how such a framing can be altered to better account for socio-political contexts and corresponding social dynamics. 


\section{Current understandings of informal social protection}

Informal practices of support have been recognised as a vital aspect of individuals' welfare in the global South. Thereby, scholars started to rethink social welfare by encountering incompatibilities of welfare models cultivated in the global North with economic, political and social contexts of the global South. These recognitions in turn lead to an upsurge in studies that looked at prevailing interpersonal practices of support in Southern contexts, leading in turn to altered classifications of welfare and redistribution, particularly pointing to informalities (Bevan 2004; Wood and Gough 2006; Wood 2004; Gough 2013). Hereby, the altered typology of welfare regimes, such as 'informal security regimes' or 'insecurity regimes' replaced labour markets with the 'idea of livelihoods' (Gough 2013) and incorporated non-state activities as sources of redistribution (Wood and Gough 2006). Hence, informal social protection (ISP) has gained recognition as a fundamental component of the 'welfare package' in the global South. In the following, I pay particular attention to the sub-set of practices among individuals. Accordingly, non-state practices that however have a degree of organisational structure, e.g. informal lenders or community funds, are not subject to the debate presented in this paper.

A multitude of studies then devotes attention to understanding the 'inner workings' of the underpinning social mechanisms. These studies generally apply a network perspective or generally acknowledge the dynamics of social relationships. For instance, Calder et al. (2014) assessed who is included, excluded or included on unequal terms in informal safety nets. Others paid attention to which types of relationships, such as family, neighbours and friends, play a role and remain available in accessing support (Arnall et al. 2004), or assessed support through a lens of mutual insurance (McDonald, Schiller, and Ueda 1999), testing whether it can cope with various types of shocks (Heemskerk, Norton, and de Dehn 2004).

Studies also discuss different roles of individuals or households and point to certain disincentives and disadvantages that can arise. Wood and Gough describe support relationships depicting elements of hierarchy and asymmetry as resulting in 'problematic inclusion, or adverse incorporation, whereby poorer people trade some short-term security in return for longer-term vulnerability and dependence' (Wood and Gough 2006: 1696). A study situated in rural Ethiopia found that kinship networks impose moral obligations of redistribution on its members, which lead to a discouragement of wealthy members to increase their income, whereas relatively poor network members appeared to be discouraged to improve their income situation owing to the comfort provided by the safety net 
of their family (Werger 2009). Furthermore, in South Africa, individuals attempted to evade traditional sharing norms by 'accumulating durables that are nonshareable at the expense of durables that may be shareable and reducing savings in liquid assets', which ultimately resulted in more extensive kinship networks with lower incomes (Di Falco and Bulte 2011: 1128). In sum, these studies suggest certain internal imbalances within such systems as has also been found within the Black Tax narrative. While personal practices of support seem to benefit some, they seem to constitute burdens or disincentives for others. A critical stance describes such kin systems as a 'poverty trap' as well as the 'collective force of conservatism' that can maintain its members at the expense of the individual (Hoff and Sen 2005).

While these studies provide valuable insights, they seem to pay less attention to the lived experience of support for different individuals. This is not to say that social practices of support generally remain misunderstood but potentially miss certain dynamics. In the following, I draw out two main aspects of framing support practices as 'informal', causing a dominant understanding which in part disregards the socio-political context, the social relationships and meaning of support.

First, practices considered under ISP are predominantly assessed in terms of their compatibility with formal systems reflected in their 'economic potential', as well as 'adequateness' or 'efficiency' to deal with certain hazards. Terms such as risk sharing, inclusion, poverty reduction, consumption smoothing, or inequality decreasing enter those debates (see for example Cox and Fafchamps, 2007; Di Falco and Bulte 2011, 2013; Werger, 2009). Support is then often categorised within the context of poverty or welfare provisioning, assessing its changes in terms of reduced, increased, present or absent interactions among individuals. To recall, these perspectives further create a linkage between the nature of practices and specified consequences, for example sharing norms creating a disincentive for individuals to invest in long-term, sharable assets (Werger 2009). They also acknowledge that the nature of practices can be shaped by external circumstances, for example describing the role of kinship in risk mitigating practices (Di Falco and Bulte 2013). However, there seems to be a rather static and categorical understanding of why and how support practices are placed differently in a person's life and context. More specifically, these studies might overlook dynamics meriting non-economic principles. This is despite a general recognition that support practices take place 'outside the market', characterised by their 'non-written, non-formalised, (and) unpredictable nature' (Laferrere and Wolff 2006: 5).

Second, studies on ISP often zero in on marginalised, rural, or poor communities (Arnall et al. 2004; Calder and Tanhchareun 2014; Devereux 1999; Heemskerk, Norton, and de Dehn 2004; McDonald, Schiller, and Ueda 1999; Werger 2009). 
Thus, they rarely draw comparisons or examine how such mechanisms differ on a broader scale or across groups. This particularly concerns groups of varying socioeconomic status but also - and often interlinked - ethnic identities. Especially within urban spaces, such social identities might blend and differ, a reason why differences and boundaries depicted by behavioural patterns can provide different insights on how social support responds to its socio-political context.

In the following, I explore the Black Tax narrative as an alternative lens to understanding practices of ISP. In particular, how this framing can alter existing understandings of such. 


\section{Centring the Black Tax narrative}

In the following, I briefly introduce the context and background of this research. It is based in Namibia, a country in Southern Africa that shares borders with South Africa, Angola, Zambia, Zimbabwe and Botswana. As a former German colony named South West Africa from 1884 to 1919, Namibia remains the only African country that has been administered by another African country, first being occupied by South Africa in 1915 and coming under South African administration from 1915 to 1990. During the 1960s, when former colonies and trust territories progressively gained independence, international pressure on South Africa grew to revoke its mandate over Namibia1. However, it took another 30 years and a border war before Namibia gained its independence on March $21^{\text {st }}, 1990$. It was under the rule of South Africa that apartheid politics and policies were introduced in Namibia. Though such policies were revoked when Namibia gained independence, the country's government and its people were faced with high levels of inequalities regarding wealth but also access to public services, opportunities and resources. On an aggregated level, income inequality measured by the GINI coefficient showed levels of $0.70,0.60$ and 0.59 in 1994, 2004 and 2010 respectively, ranking among the ten most unequal countries (World Bank, 2017). Only a minority of people depict the living standards expected in an upper middle income country (Namibia Statistics Agency and World Bank 2017).

Black Tax is a colloquial term that in part speaks to former and continued inequalities. It is a term that exists in Namibia and South Africa alike. While there is a paucity of empirical studies on Black Tax in Namibia, it nevertheless features prominently in the country's public discourse and media. I thus primarily draw on Namibian national media outlets and the available wider literature from South Africa to understand the Black Tax narrative more broadly.

Black Tax is a recent term in Namibia and South Africa. Before the term itself existed, it used to revolve around 'old African traditions' that entailed mutual caretaking of families, kinship and community. It was seen as family duty, family responsibility, but also family upliftment (Mhlongo 2019). While the term 'Black Tax' does not necessarily seem to be known or used by older generations (Busani-Dube 2019), some attribute its origin to economic recessions and socioeconomic implications that affected black individuals differently.

South Africa was assigned administration of Namibia, formerly known as South West Africa, by terms of Article 22 of the Covenant of the League of Nations. Namibia was classified as a C Mandate by the League Council, which referred to countries deemed as being least developed; thus, South Africa was assigned full legislation and administration of the country. 
A traditional way of life - or communal life as African way of life - seems to depict a somewhat negative connotation for younger generations. Material caretaking used to be a 'neutral' practice across the lifecycle. External challenges due to economic recessions and resulting unemployment in the late 2000s increased economic pressure for those who are typically referred to as black middle-class. In light of decreasing resources to cater for one's own and other's needs, the sharing of resources became referred to as 'tax' (Mhlongo 2019). For some, Black Tax 'unintentionally demonise(s) the idea of family upliftment by calling it some kind of Black Tax' or an 'abusive cultural practice, (including) a burden on black people's progress' (Mhlongo 2019: 82). Further, the author describes that some black individuals felt the pressure to retreat from a traditional way of life.

In her master's dissertation, Magubane (2017) generally describes two schools of thought when referring to Black Tax. In one, it seems to be attributed to the discrimination of the apartheid system and the continued inequality as a result of such. The other primarily focuses on the black middle-class and their financial support to extended family members in light of continued inequalities resulting from apartheid. While both do not differ in identifying the cause, namely historical inequality, the latter points to the fact that shifting up in terms of socioeconomic class bears consequences for black individuals. In fact, Busani-Dube (2019: 17) states that 'success comes with expectations; it comes with the responsibility to send the elevator back down to fetch the others'.

However, whether these responsibilities, expectations or consequences more broadly are perceived as a positive or negative dynamic differs. While some acknowledge that 'Black Tax is not our culture, it has everything to do with the position apartheid has put us [non-white individuals] in' (Busani-Dube 2019: 19), some state that it has been an 'intimate part of my life; I did not even give it a name' (Sithole 2019: 158). Others see it as a flawed social construct whereby calling it 'tax' is 'premised on the selfish, capitalist attitude of 'me first' and I was not raised that way. Therefore, I reject it with contempt' (Mofokeng 2019: 109). More positive stances refer to it as family investment with potential multiplying effects, as well as being a tool to address inequality (Mncube 2019). In sum, the term itself has no universal understanding, let alone definition, nor is it accepted and used by everyone.

Regardless of whether it is seen as a burden or a blessing by some and not others, there are a few more general dynamics, which refer to the previously introduced perspectives of this study. Central is the element of individual merit, as economic success in the form of educational attainment and employment as well as one's age. This individual merit comes with the expectation to be divided and sub-divided through economic support given to extended family members. This can cause one to 'defer your dreams in order to accommodate the 
immediate and pressing needs of others within your orbit' (Khumalo 2019: 30) but also to pay (or literally repay) attributes to those who have helped realise one's economic success. It further comes with unwritten rules of 'family first' or 'not saying no to those who raised you' (Busani-Dube 2019), but also to ensure that 'family roots and communal structure are not destroyed by the so-called alien civilization of an individualistic lifestyle' (Mhlongo 2019: 85). This also indicates a collision between traditional norms and lifestyles and modern lifestyles within the same economic and social context.

In sum, while framed as a normative, social script that individuals follow within the confines of family, why and between whom Black Tax is mobilised seems to be associated with changing socioeconomic statuses among family members. For instance, this can be found in statements which describe it as '[a practice which] ...many young black working professionals have to endure as part of their career successes in the modern world' (Mushaandja 2015:1) as well as a 'cultural and moral obligation that people feel towards their families... (which) feeds an expectation that a person may be liable to carry a burden if they studied and found a job' (Mtolo 2018: 1).

Similarly, a recent article suggests that Black Tax is an 'affective term that is associated with shifting social identities' (Mangoma and Wilson-Prangley 2019: 444), whereby this shift is then understood as becoming or being 'better off', causing individuals to support '...their economically disadvantaged family' (Mangoma and Wilson-Prangley 2019: 447). Therefore, the authors point to the fact that 'balancing one's own personal growth ambitions against cultural and social pressures can create internal conflict' for those who provide support (Mangoma and Wilson-Prangley 2019: 456). More broadly, it has further been argued that 'Black Tax does the real work of income redistribution in the country', which deals with 'apartheid('s)... socially engineered black poverty... and makes the need for Black Tax a reality' (Ndinga-Kanga 2019: 1).

In the following, I draw out how the Black Tax narrative brings a novel perspective to discussions on ISP. It provides a unique opportunity to explore a social narrative, which is meaningful for and resonates in the social life of Namibians.

First, Black Tax is not a uniform mechanism. As discussed in this section, it is dependent on an individual's position but can also have a different meaning and understanding attached to support practices in general. In that, it calls for an exploration of varying motivations and intentions of support practices. Doing so, one can explore support practices beyond economic principles and provide new insights to the 'functions' of ISP.

Second, Black Tax furthers the debate on ISP by calling upon social group differences across racial or ethnic identities which generally remain under- 
acknowledged. For instance, it indicates the varying extent of socioeconomic heterogeneity and potential necessities and responsibilities to provide support within certain identity groups. It is thus equally a story about vertical and horizontal inequality: vertical inequality between non-white individuals who are better off than others, finding themselves in positions to support others - which might speak to the notion of 'sending the elevator back down' (Busani-Dube 2019); and horizontal inequality in that these support dynamics seem to apply to non-white and not white individuals, but also in that they respond to economic disadvantages for non-white, and not white individuals. It therefore provides an interesting case to explore a bi-directional relationship: between socio-political systems and collective behaviours - comparing within-group dynamics against the backdrop of systematic between-group differences. It thereby alters understandings of ISP beyond the conceptual space of rurality, or poverty. 


\section{Data and definitions}

In this research, I explore networks of support to revisit understandings of internal dynamics. I introduce the lens of horizontal inequality accounting for Namibia's socio-political context and the former apartheid regime. At the centre of my empirical investigation is the interpersonal space: this being social relationships between individuals that function as social channels for support. This research thus follows a general recognition that a person's life and wellbeing are connected to others (Simmel 1955; Lin 2002). To reflect this notion, I apply personal networks as a corresponding methodological framework to explore support activities and context through the Black Tax narrative.

\subsection{Definition of support}

For the purpose of this study, support activities are clustered into four thematic areas as shown in Table 4.1. This clustering largely stems from empirical insights into support practices in the Namibian context. Previous studies found evidence for various types of support salient in people's lives and socioeconomic contexts (Pearson 1986; Sarason and Sarason 2009). Due to their primary focus set on poor communities or households, insights largely cover those of non-white Namibians. This is due to the continued economic stratification across ethnic identities due to the former apartheid system. In the following, I discuss support practices in the Namibian context.

Support entails general caregiving and shared household arrangements, including the role of the elderly as caregivers towards vulnerable children (Kalomo 2018). Greiner (2010) also pointed to the trend of younger generations moving to urban areas owing to education and employment opportunities whereas older generations stay in rural areas, which results in different household compositions in urban and rural areas. Further, Tvedten and Nangulah (1999) describe the practice of sending children to rural areas for childcare purposes, as well as 'watching each other's children' among urban neighbours. In addition, Ruiz-Casares (2010) found evidence for peer-to-peer support among younger individuals living in youth-headed households. In order to account for different household living arrangements and care practices in Namibia, I include the thematic area 'co-habitation, unpaid labour, and care', covering shared living arrangements, household and work assistance as well as caregiving for the elderly and children.

Another observation concerns financial support. An earlier study observed the practice of financial contributions in Namibia around certain life events including funerals and weddings, but also the general practice of interest-free loans among relatives and neighbours or sharing social pensions (Subbarao 1999). More 
broadly, the framing of Black Tax itself primarily concerns financial support as a form of care (see for example Mncube 2019). Therefore, I include financial support to capture transfers of different amounts to reflect both contributions to smaller daily expenses as well as larger sums as contributions to life events.

\section{Table 4.1 An economic welfare-based framework for social support}

\begin{tabular}{|c|c|}
\hline Thematic areas & Corresponding activities \\
\hline $\begin{array}{l}\text { Co-habitation } \\
\text { Unpaid labour \& } \\
\text { Care }\end{array}$ & $\begin{array}{l}\text { Sharing of accommodation including or excluding bills } \\
\text { Household assistance, e.g. helping with household } \\
\text { chores, gardening, repairs, etc. } \\
\text { Caring for elderly/caring for someone else's children, e.g. } \\
\text { providing food, shelter, spending time } \\
\text { Unpaid assistance at work, e.g. covering shifts, sharing of } \\
\text { knowledge, helping with tasks }\end{array}$ \\
\hline Financial support & Varying amounts from $100 \mathrm{NAD}^{2}$ to more than $5000 \mathrm{NAD}$ \\
\hline In kind support & $\begin{array}{l}\text { Land } \\
\text { Livestock } \\
\text { Non-durable goods, e.g. food, clothing, fuel, other } \\
\text { consumables } \\
\text { Durable goods, e.g. furniture, building material, transport } \\
\text { vehicles, fridge, TV, etc. }\end{array}$ \\
\hline $\begin{array}{l}\text { Opportunity } \\
\text { sharing }\end{array}$ & $\begin{array}{l}\text { Sharing of job vacancies and contacts } \\
\text { Hiring through (personal) contacts } \\
\text { Assistance when applying for jobs, e.g. reference letters, } \\
\text { help with application forms, mentoring } \\
\text { Sharing of educational opportunities, e.g. about trainings, } \\
\text { scholarships, etc. } \\
\text { Assistance when applying for education, e.g. filling out } \\
\text { forms, reference letters, etc. }\end{array}$ \\
\hline
\end{tabular}

Author's own classification, building on empirical studies in the Namibian context.

Alongside financial support, in-kind support equally plays a role. Studies found evidence for the practice of providing food across the urban-rural space (Frayne 2001 ; 2004) among individuals (Schnegg 2015). Furthermore, Tvedten and Nangulah's study (1999) observes the sharing of other non-food items such as agricultural products, clothes or tools depending on a person's need. Furthermore, gifts for weddings and other life events can also be given in the form of livestock in Namibia (Subbarao 1999; Bond 2011). In addition, land is a long-disputed issue regarding access and ownership, remaining skewed towards 
former colonial structures and associated ownership (Melber 2005). The thematic area 'in-kind support' will control, on the one hand, for observed, nondurable and durable in-kind support as well as larger transfers of 'wealth' concerning livestock in connection with certain life events, as well as land transactions regarding ownership structures.

Lastly, Tvedten and Nangulah's (1999) account of support practices also described the 'seeking of occasional work' or 'other good things'. While this area is less explored and defined in Namibia, the thematic area of 'opportunity sharing' builds on general evidence of job information sharing and referrals among individuals (for a general review of job information networks, see for example loannides and Datcher Loury 2004). The thematic area 'opportunity sharing' thus primarily focuses on the sharing of vacancies, job contacts, and assistance during one's education.

\subsection{Relevant data}

In this study, I draw on 205 personal networks. Across those personal networks, individuals recorded a total of 5,732 support activities. Apart from collecting content about the characteristics of the mentioned contacts of respondents (hereinafter referred to as alter) and the respondents themselves (hereinafter referred to as ego), including their age, education or similar, I also asked about particulars of the support activity. This was to know more about individuals' understanding of support.

More precisely, I asked about how often the activity takes place or took place, but also about the motives and intentions associated with the activity. Some of the listed activities were more specific and thus resulted in a narrower range of related motives and intentions. For instance, sharing accommodation with someone was linked to a more specific range of intentions, e.g. moving for a job or, more broadly, affordability of housing in a given area. Providing someone with an amount of money showed a greater range of motives, i.e. it has been used for education, leisure, starting a business, buying a car, or contributing to someone's funeral. A greater span of intentions might also make a support activity more likely to be recorded owing to various applications in an individual's life. The nature or value of support might further impact on the frequency of mentioning a given support activity. For instance, transfers of land typically happened as an activity associated with one particular alter whereas caring for an elderly person or caring for someone else's children could involve multiple different people and thus generate multiple support ties.

Table 4.2 provides an overview of variables of interest in this paper in particular. Each column displays the percentage of either egos or alters observed for a particular category, say the percentage of egos who hold a secondary degree or 


\section{Table 4.2 Age, education, and labour status across ethnic identity groups}

\begin{tabular}{|c|c|c|c|c|c|c|c|c|}
\hline \multirow{3}{*}{$\begin{array}{l}\text { Sample } \\
\text { characteristics }\end{array}$} & \multicolumn{2}{|c|}{ All } & \multicolumn{3}{|c|}{ Egos } & \multicolumn{3}{|c|}{ Alters } \\
\hline & Ego & Alter & $\mathrm{NW}^{*}$ & $W$ & Chi Sq. & NW & $W$ & Chi Sq. \\
\hline & 205 & 5732 & 165 & 40 & 205 & 4714 & 1018 & 5732 \\
\hline Age group & & & & & $\chi^{2}(5)$ & & & $\chi^{2}(5)$ \\
\hline Minors & . & 15.4 & . & . & 1.44 & 22.3 & 10.8 & 78.76 \\
\hline Young Adults $^{* *}$ & 20.3 & 27.6 & 20.9 & 17.9 & $p=0.836$ & 22.4 & 24.2 & $\mathrm{p}<0.001$ \\
\hline $\begin{array}{l}\text { Lower Middle- } \\
\text { Aged Adults }\end{array}$ & 20.8 & 18.8 & 20.3 & 23.1 & $\varphi=0.08$ & 19.1 & 16.7 & $\varphi=0.12^{\mathrm{a}}$ \\
\hline $\begin{array}{l}\text { Upper Middle- } \\
\text { Aged Adults }\end{array}$ & 21.8 & 12.8 & 20.9 & 25.7 & & 12.3 & 13.3 & \\
\hline Older-Aged Adults & 18.3 & 10.4 & 19.6 & 12.8 & & 9.7 & 13.9 & \\
\hline Elderly & 18.8 & 15.4 & 18.3 & 20.5 & & 14.3 & 21.1 & \\
\hline Education & & & & & $\chi^{2}(3)$ & & & $\chi^{2}(3)$ \\
\hline None & 6.8 & 19.8 & 10.3 & 0.0 & 26.22 & 21.3 & 13.4 & 244.10 \\
\hline Primary & 12.6 & 21.2 & 20.0 & 0.0 & $p<0.001$ & 23.3 & 11.4 & $p<0.001$ \\
\hline Secondary & 30.2 & 27.2 & 33.9 & 22.5 & $\varphi=0.35^{\mathrm{a}}$ & 28.1 & 23.5 & $\varphi=0.21^{\mathrm{a}}$ \\
\hline Tertiary & 50.4 & 31.8 & 35.8 & 77.5 & & 27.5 & 51.8 & \\
\hline $\begin{array}{l}\text { Labour } \\
\text { status }^{\star * *}\end{array}$ & & & & & $\chi^{2}(2)$ & & & $\chi^{2}(2)$ \\
\hline $\begin{array}{l}\text { Income from } \\
\text { labour }\end{array}$ & 66.5 & 46.1 & 64.2 & 85.0 & 9.09 & 61.8 & 83.6 & 283.74 \\
\hline Unemployed & 7.9 & 15.7 & 10.9 & 0.0 & $p=0.028$ & 9.6 & 0.0 & $p<0.001$ \\
\hline Not in labour force & 25.6 & 38.2 & 24.9 & 15.0 & $\varphi=0.21^{a}$ & 28.6 & 16.4 & $\varphi=0.22^{\mathrm{a}}$ \\
\hline
\end{tabular}

Notes:

${ }^{*} \mathrm{NW}=$ non-white, $\mathrm{W}=$ white,

${ }^{* *}$ Minors are individuals aged below 18 (applies to alters only). Young Adults are individuals aged 18 to 30 years. Lower Middle-Aged Adults are individuals aged 31 to 40 years. Upper Middle-Aged Adults are individuals aged 41 to 50 years. Older Aged Adults are individuals aged 51 to 65 years. Elderly are individuals above 65 years. These age groups were also applied in the sampling process.

${ }^{* *}$ Labour status is coded along the rationale whether the individual has a source of income via labour. Income from labour includes the following categories (derived from ISCO 2008): managers, professionals, technicians and associates, clerical support workers, services and sales support workers, skilled agricultural workers, craft and related trade workers, plant and machine operators, elementary occupations, armed forces occupations, and informal labour. Unemployed included individuals who stated that they were currently unemployed and typically have no income via labour. Not in the labour force includes individuals below the legal working age, those who are retired or pensioners, those who perform unpaid labour (e.g. household chores), or who are currently in education.

Source: Primary data, collected 2017/18. Notes: Testing differences across ethnic identity groups using Chi square tests of independence, $\varphi=$ effect size (Cramer's V), a Constitutes a significant difference with an effect size $\geq$ to Cohen's definition of 'small'. 
Ethnic identity groups are aggregated as non-white and white (see Annexe 1 for detailed overview). This aggregation does not represent a homogenisation of ethnic identity groups in terms of their cultural practices and social dynamics. What gives meaning to this dualistic lens is the focus on historically grown inequalities. Whether historical systems discriminated against some ethnic identities and not others can present a binary answer: yes, systematic discrimination applied to non-white ethnic identities and no, this systematic discrimination did not apply to white ethnic identities. This discrimination then acted in a mirrored way: discrimination against black identity groups were designed in a way to create favourable treatments for white identity groups. I thus account for ethnic identities owing to their former instrumentalisation in generating differentiated access, rights and opportunities. This has created unequal socioeconomic positions for individuals, which followed a systemic, politically crafted rather than an opportunistic or individually driven process. Subsequently, I summarise the main patterns that can be initially observed across age, education and labour status.

An individual's age in completed years is aggregated into age groups, which were also employed during the sampling process; hence age compositions do not differ significantly across non-white and white egos. While the sample only included egos above the age of 18 , egos were able to report alters below that age threshold. Hence, for alters there is an additional category which employs Namibia's legal age of 21 years to distinguish minors from young adults. Egos were on average 44 years of age with the youngest being 18 and the oldest being 84 years old. From the perspective of the ego, one can see that support tends to have a 'downward orientation' in terms of age. Combined, 43.0 per cent of support activities involve alters who are minors or young adults. This is plausible as some support activities might be linked to parental care obligations. This pattern significantly differs when disaggregating alters by whether they are tied to a white or non-white ego. The combined share of support for minors and young adults amounts to 44.7 per cent for alters of non-white egos compared to 35.0 per cent for alters of white egos. A slightly higher share for non-white ethnic identities might reflect larger family sizes or a wider understanding of family and care obligations, as well as linking back to the fluidity of household boundaries, as has been previously observed in Namibia (Greiner 2010; 2012).

Education is defined as completed education level and ranges from having no education to tertiary degree holders. With regard to observed alters, shares of education levels might be a function of age: with alters including minors, a larger share might also hold lower educational levels since they might still be pursuing a degree. Though it is noteworthy that there is a significant difference whereby alters associated with white egos hold a tertiary degree more frequently than non-white egos (51.8 per cent versus 27.5 per cent). However, with regard to egos including adults only, education levels might be more conclusive in terms of 
their socioeconomic standing, particularly across ethnic identity groups. Overall, the sample includes a considerable share of tertiary degree holders (50.4 per cent of all egos). This might be owing to most sampling taking place in Windhoek ${ }^{3}$. What is noteworthy is the significantly different spread of education levels across ethnic identity groups. Among white egos, the sample does not include any individuals who have either completed no or only primary education with most (77.5 per cent) holding a tertiary degree. While this might in part be owing to the sampling location and accessibility of study participants, it might also reflect the absence of former discrimination regarding educational outcomes for white ethnic identities. Among egos, there is a share of 10.3 per cent and 20.0 per cent of non-white egos who completed no and/or primary education only with 35.8 per cent holding a tertiary degree.

Lastly, labour status captures whether an individual has a source of labour income. It employs the categories laid out in the ISCO framework and distinguishes them to broadly compare whether an individual has a source of income via labour, or whether they are currently unemployed in the labour force. This thus presents a broader comparison rather than zooming in on professional levels per se. Similar to the education levels observed, a considerable share of egos have an income source via labour (66.5 per cent). Overall, 7.9 per cent of egos are unemployed whereas 25.6 per cent are currently not in the labour force, being retired or in education. The share of reported alters who are unemployed is slightly higher overall, amounting to 15.7 per cent. This could indicate that a share of support activities might respond to needs resulting from the absence of labour income. Again, shares across labour status vary across ethnic identity groups. Again, among white egos, the sample does not include any individuals reporting unemployment. Among non-white egos, 10.9 per cent are unemployed. Further, the share of egos having an income via labour is slightly lower at 64.2 per cent (non-white) versus 85.0 per cent (white). Furthermore, no white ego reported support activities with an unemployed alter whereas this amounts to 9.6 per cent of support activities for non-white egos.

Generally, these comparisons are insightful to get a brief overview of socioeconomic and demographic compositions of the sample. However, percentage shares remain inconclusive about the aspect of who tends to be linked to whom - a primary aspect of network data. For example, is an ego with a tertiary degree more linked - through support activities - to an alter who also holds a tertiary degree? Subsequently, I explore these dynamics further.

3 Generally, socioeconomic statuses are higher in urban than rural areas in Namibia (Namibia Statistics Agency 2017). This might be one explanation as to why the study's sample shows a higher share of tertiary degree holders. Another aspect could be that technical degrees were considered as tertiary degrees in the Namibian context, leading to greater assignment of individuals to the category of tertiary degree holders. 


\section{Analytical strategy}

This study is informed by personal network data which is a sub-classification of social network analysis' ${ }^{4}$. This data does not only facilitate a 'relational perspective' but also the computation of specific measures and patterns as I shall detail below. More broadly, the analysis is built on a rationale of bidirectionality as proposed by Sarason and Sarason (2009). The authors view 'support from a bidirectional perspective that integrates what people bring to situations with what situations do to them. In the following analysis, I adopt a bidirectional perspective Personal relationships grow in a mixture of the objective (what happens) and the subjective (what each person is thinking about, able to do, and looking for)' (Sarason and Sarason 2009: 115). I thus combine network measures with statements of the lived experience of support. In other words, I combine more structural, objective measures of individuals' situations with the subjective nature and thus how individuals make sense of support activities.

\subsection{Network measures}

Network measures typically function to describe the composition of networks along various criteria. I focus on measures that can be applied to ego-centric or personal networks. Personal networks ${ }^{5}$ do not provide information about the larger structure of social networks per se but present localised zooms into larger structures. The personal networks included in this study contain first level edges, and thus only represent the immediate environment of the individual. In network terminology an edge represents a relation between two nodes. It thus connects two nodes, whereby nodes present the entities connected by an edge (Newman 2010). Within the context of this study an edge thus captures a reported support activity and a node presents an individual, being a provider or receiver linked through that activity.

I apply the following network measures to sketch and provide a general overview of personal networks of support. I focus on edge dispersion and ego-alter similarity. Here, ego refers to the person who reported their personal networks whereas alters are contacts the ego mentioned as being part of their network.

4 Complete networks would comprise all connections observed for a population of interest. Personal networks capture only local environments of such networks, focusing on the immediate connections of individuals.

5 Personal networks generally contain the immediate contacts of an individual (first level) and can also display connections among contacts (second level). Thus, personal networks do not capture a complete social network in a given setting. They rather constitute a set of networks, namely one for each respondent. Personal networks can be a more feasible framework when collecting primary network data as one can sample randomly from given populations and the number of immediate contacts mentioned by an individual "tends to be fairly small... leading to data of manageable proportions" (Perry, Pescosolido, and Borgatti 2018, 28). 
Edge dispersion refers to the distribution or variation of relations across egos, or ego, edge or alter attributes (Crossley et al. 2015). In this study, they capture how many edges - on average - an ego reported given specific criteria, as I shall explain in the following. For example, edge dispersion can indicate how many edges an ego has depending on whether the ego is a young adult or elderly person. It can also be disaggregated by edge attributes, for example how many regular versus occasional versus single event support activities an ego reported on average. I primarily focus on ego attributes including the ego's age and socioeconomic indicators, as well as selected edge attributes being support temporality and the type of support activity.

Ego-alter similarity is then a summary measure of edge dispersion. It captures the degree of similarity between the ego and their mentioned alters across various criteria. For instance, similarity can capture whether most of an ego's alters are in the same age group as the ego. In light of this, it is interesting to see certain social markers of assimilation or indicate whether - on average - a person is more likely to engage with some individuals but not others. My data showed that, when explicitly asked about similarity, ethnic identity turned out to be such a marker. Through exploring similarity, I explore whether there are other markers within these systems and how they differ. This includes previously explored criteria including age, education and labour status. A prominent measure is the External-Internal Index (EI) developed by Krackhardt and Stern (1988). It takes the number of edges external to a certain group (say support activities to alters who are not of the same age group as the ego) minus the number of edges that are internal to that group (say support activities to alters who are of the same age group as the ego) and divides that balance by the total number of edges (and thus all observed support activities of that ego). The EI index can range from -1 to 1 , whereby -1 indicates that all edges are internal (e.g. same age group), 0 indicates that there are as many external as internal edges (equal amount of the same and different age groups) and 1 indicates that all edges are external (e.g. different age group). The observed values of the index are displayed as a fraction - divided by the total number of edges -, i.e. 0.7 would indicate a balance displaying more external edges.

\subsection{Thematic analysis}

The purpose of this analysis is to explore the lived experience of support paying attention to the variety of what seemingly the same support activities mean for different people. Naturally, there are some patterns in meanings that can emerge. I use them as themes within which there is still room for a discussion of variety. I therefore follow an approach similar to the six steps of thematic analysis suggested by Braun and Clarke (2012). Generally, thematic analysis 'is a method for identifying, analysing, and interpreting patterns of meaning ("themes") within qualitative data' (Clarke and Braun 2017: 297). It 
thereby provides a flexible approach with regard to meaning generation as it '....can be used to identify patterns within and across data in relation to participants' lived experience, views and perspectives, and behaviour and practices; experiential ... to understand what participants think, feel and do' (Clarke and Braun 2017: 297). Within the context of this study, it thus provides a useful tool to explore the variety as well as meanings of support activities across individuals and within broader social groups by race. In the following, I follow the steps proposed by Clarke and Braun (2017).

Based on an inductive approach, I begin with a familiarisation of the data. To recall, personal statements are mainly linked to support activities that were provided by respondents. Questions about 'why one supports' somehow naturally capture the perspective of the provider. I specifically use the structural findings on network compositions to guide my focus as well as sub-selections of personal statements considered in respective explorations. For example, if a network pattern indicated a particular difference across social groups (by race) with regard to a certain support activity attribute, say its temporality, I would select all support activities and associated statements which carry the attribute 'regular support'. Thereby the temporality of support is derived from quantitative information capturing the frequency of support.

Second, I would identify emergent themes, for example do statements reflect the content and function of support, do they mention the underpinning social relationship, a notion of obligation or dependency within such relationships, or similar? Thereby, I would look for certain phrasings and repeated words and meanings within personal statements.

Third, I generated themes based on pairings of initially identified emergent themes. For instance, to see whether mentioned underpinning relationships also entailed mentioning the function of support. Doing so allowed me to combine different meanings of respondents reflected within statements rather than focusing on just one element within those.

Fourth, I reviewed evolving themes. I paid attention to whether they were largely distinguishable without too much overlapping or which type of overlapping they would display. For example, which other combinations were to be found when mentioning underpinning social relationships and if these alternatives are different from the pre-identified ones. Apart from consistency, I also paid attention to how they match the structural findings found in the exploration of network compositions in order to be able to link structure and meaning during the interpretation stage.

Fifth, I defined and named themes within the focus areas. I used labels and descriptions of the emergent as well as generated themes in order to demonstrate how final meanings and general patterns therein build on multiple 
elements. Defined themes are based on initial wordings of respondents and can be seen as a topical heading, capturing variety within them rather than a defined scale or classification. Lastly, I write about themes by incorporating different stages of coding and themes to add transparency and illustrate variety within them. I also include an overview of steps and examples taken in the process in Annexe 2.

I draw on personal statements of individuals associated with provided support activities. I only asked about the motives and intentions when they provided support owing to a general perception that the provision of support is more an action requiring a decision than receiving support from someone else. Asking respondents about someone's motives and intentions from whom they received support might mix a process of self-reflection with reflections about other's behaviour and thus cause inconsistencies in exploring one's own motives. The interview included questions on 'what was the cause to provide ... activity' as well as 'what was your motivation to provide ... activity'. The first one can be understood as someone's intentions, capturing the purpose of a given support activity. The second one can then be understood as one's motives being the reasons for engaging in a certain activity. Both provide different angles on why a support activity took place - from a more pragmatic sense (intentions) as well as a potential emotional place (motives). Using those personal statements and their chosen phrasing can represent a nexus of meaning, context and action and thereby a more complete picture about the individuals' experiences of support. 


\section{Compositions and structures of personal networks}

Across all personal networks, the sample comprises a total of 3,365 unique alters who are mentioned across the 5,732 support activities. These support activities are spread across the four thematic dimensions of support. Most egoalter relations were deep in term of duration, closeness and importance. Generally, out of mentioned alters in their respective support network, 41.7 per cent were individuals that the egos have known since their birth. They felt very close to more than half of their mentioned alters (56.3 per cent) and, on average, considered 73.1 per cent of their support activities as being very important to them.

\subsection{General patterns of personal networks}

Table 6.1 displays measures of network compositions. Most figures except for network density explained in the following refer to the average number of support activities observed. For instance, network size displays the average number of activities (mean degree) observed across all egos. Subsequently, mean degrees are disaggregated by type of support, temporality of support and socioeconomic characteristics of the ego. Mean degrees thus then refer to the average number of support activities observed only looking at financial support activities or only looking at egos who hold a secondary degree, for example. Overall, personal networks were fairly extensive in terms of activities mentioned, covering on average about 28 support activities.

However, networks also show a moderate density, and thus a tendency to be somewhat closed. Density also understood as network closure is a measure of social heterogeneity by calculating the number of unique individuals (nodes) divided over the total number of support activities (edges) of an ego. Accordingly, if an ego mentioned 12 unique alters and 12 support activities, density would amount to one and indicate total social heterogeneity. Lower values thus indicate that an ego engages with fewer alters across multiple support activities. In this study, the network density amounts to 0.62 , which indicates that on average 60 per cent of support activities are linked to a unique individual in personal networks whereby 40 per cent then involves re-mentioning previously stated alters. It can be said that different support types seem to draw on a more diverse set of contacts, however, a considerable amount of multiple mentioning of alters occurs. 


\section{Table 6.1 Compositions across personal networks}

\begin{tabular}{lll}
\hline Composition across personal networks & \multicolumn{2}{l}{ All Egos (N = 205) } \\
\hline Network measures & $\begin{array}{l}\text { Mean } \\
\text { Degree }\end{array}$ & SD \\
\hline Degree & 27.9 & 13.01 \\
\hline Density & $.62^{* *}$ & .19 \\
\hline Effective size & 16.4 & 8.2 \\
\hline Type of support & & \\
\hline Co-hab.,unpaid labour and care & 7.0 & 4.83 \\
\hline Financial & 7.4 & 4.95 \\
\hline In-kind & 6.4 & 4.53 \\
\hline Opportunities & 7.1 & 5.15 \\
\hline Temporality & & \\
\hline Regular & 14.5 & 10.79 \\
\hline Occasional & 6.5 & 6.28 \\
\hline Single/ rare event & 7.0 & 5.71 \\
\hline Ongoing (ref.cat.: past) & 18.5 & 10.96 \\
\hline Age- Ego & & \\
\hline Young Adults & 27.4 & 12.17 \\
\hline Lower Middle-aged Adults & 27.3 & 14.00 \\
\hline Upper Middle-aged Adults & 27.4 & 12.13 \\
\hline Older Aged Adults & 26.4 & 16.50 \\
\hline Elderly & 32.8 & 24.28 \\
\hline Support edge with minor & 3.8 & .37 \\
\hline Education & & \\
\hline None & 27.2 & 18.73 \\
\hline Primary & 22.8 \\
\hline Secondary & 26.4 & 11.34 \\
\hline Tertiary & 31.1 & 17.39 \\
\hline Labour status & & \\
\hline Income source labour & 27.2 & 13.44 \\
\hline Unemployed & 25.0 & 11.70 \\
\hline Not in labour force & 31.2 & 22.62 \\
\hline
\end{tabular}

Notes:

* Note that this covers both, received and provided support. Mean degree displays the average number of support activities observed across personal networks.

${ }^{* *}$ Expressed as the average of (unique alters/ total activities observed within each personal network).

${ }^{* * *}$ Regular refers to daily, weekly and up to monthly activities. Occasional are activities that occur every 3 to 4 months, twice a year, annually or bi-annually. Single or rare events are support activities that took place once in a respondent's life.

Source: Primary data collected 2017/18, author's own calculation. 
Also illustrated in Table 6.1, the average number of activities mentioned across types of support does not vary considerably; only in-kind support activities tend to be a bit lower on average. Hereby, egos reported 6.4 support activities on average as compared to about seven for the remaining categories. Further to this, the highest average is observed for regular support activities (14.5 on average) as well as being labelled as ongoing (18.5 on average). Given the average network size of egos, this amounts to an average of 51 per cent regular and 68 per cent ongoing support activities in personal support networks. This might also be explained by the very type of support included in this study. Similarly, the number of observed support activities does not differ much across age groups. Networks appear to be slightly larger for elderly egos (32.8 activities) and slightly lower for older aged adults (26.4 activities). Tertiary degree holders tend to have slightly larger networks (31.1 activities) as compared to lower education levels (between 22.8 activities for primary education and 27.2 activities for no education completed); the results are similar for egos who are currently not in the labour force (31.2 activities compared to 27.2 activities for income source via labour and 25.0 activities for unemployed).

\section{Table 6.2 Ego-alter similarities in network composition}

\begin{tabular}{lcc}
\hline Composition across personal networks & All Egos $(\mathbf{N}=\mathbf{2 0 5})$ \\
\hline Similarity - Ego \& Alter $^{6}$ & Mean \% & SD \\
\hline Young Adults & .25 & .38 \\
\hline Lower Middle-aged Adults $_{E I}$ & .54 & .29 \\
\hline Upper Middle-aged Adults & .73 & .19 \\
\hline Older Aged Adults $_{E I}$ & .81 & .17 \\
\hline Elderly $_{E I}$ & .71 & .22 \\
\hline No Education $_{E I}$ & .12 & .48 \\
\hline Primary Education $_{E I}$ & .31 & .43 \\
\hline Second. Education $_{E I}$ & .31 & .42 \\
\hline Tertiary Education $_{E I}$ & .18 & .42 \\
\hline Income source labour $_{E I}$ & .15 & .40 \\
\hline Unemployed $_{E I}$ & .40 & .36 \\
\hline Not in labour force & .32 & .55 \\
\hline
\end{tabular}

Source: Primary data collected 2017/18, author's own calculation. Notes: Mean \% represents average El Index observed for each similarity pair. 
Table 6.2 displays results regarding Ego-Alter similarities. The figures represent mean percentages of the difference between external minus internal activities over total activities observed. External refers to the alter falling into a different category than the ego, i.e. if the ego is a young adult, an external link would be to an alter who is not a young adult. Egos mainly engage in support activities with alters of different age groups rather than their peers, particularly among older cohorts. While young adults tend to interact with peers or younger alters (external links only exceeding internal links by 25 per cent), on average older aged egos show a higher share of support activities being linked to different age groups than their own (with external links exceeding internal links by 81 per cent and 70 per cent respectively). Egos further tend to have support relationships with alters of the same education levels, particularly so for tertiary degree holders (external links exceeding internal ones by only 18 per cent). While unemployed egos interact comparatively more with alters of a different labour status (external links exceeding internal by 40 per cent), egos with labour as an income source tend to interact with alters of the same labour status (external links exceeding internal ones by only 15 per cent).

Thus, while some social identities might constitute a marker of peer to peer support (i.e. education for no education and tertiary education completed) others show a higher link for interacting with different alters (especially if the age of the ego increases).

\subsection{Structural indicators across ethnic identity groups}

In the following, I will pay attention to significant variations across ethnic identity groups. Thereby, I aim at detecting first structural patterns that can speak to aspects of the Black Tax narrative - in the broad sense that support practices differ due to former discriminatory practices.

First, as displayed in Table 6.3, egos of non-white ethnic identities reported significantly higher shares of regular support activities than egos of white ethnic identity, whereby the median of regular support activities is greater (12) for nonwhite than for white egos (nine). This is interesting as it hints at different levels of daily, weekly or monthly commitments to provide or receive support. Shorter frequencies of activities might be more closely linked to everyday needs such as buying food, household chores, or paying the monthly rent. 


\section{Table 6.3 Support temporality across ethnic identity groups}

\begin{tabular}{|c|c|c|c|c|c|}
\hline \multirow[t]{2}{*}{$\begin{array}{l}\text { Composition across } \\
\text { personal networks }\end{array}$} & \multicolumn{2}{|c|}{ white $(\mathrm{N}=40)$} & \multicolumn{2}{|c|}{$\begin{array}{l}\text { non-white (N= } \\
165)\end{array}$} & \multirow[t]{2}{*}{$\begin{array}{l}\text { Equality of } \\
\text { median }\end{array}$} \\
\hline & Median & IQR & Median & IQR & \\
\hline \multicolumn{6}{|l|}{ Temporality } \\
\hline Regular & $9^{* * *}$ & 7 & $12^{\star \star *}$ & 8 & $\begin{array}{l}\chi^{2}(1) 8.14, p= \\
0.004\end{array}$ \\
\hline Occasional & 4.5 & 6.5 & 5 & 7 & $\begin{array}{l}\chi^{2}(1) 0.00, p= \\
0.945\end{array}$ \\
\hline Single/ rare event & 5.5 & 5.5 & 6 & 6 & $\begin{array}{l}\chi^{2}(1) 0.66, p= \\
0.415\end{array}$ \\
\hline Ongoing (ref.cat.: past) & 14 & 15.5 & 16 & 11 & $\begin{array}{l}\chi^{2}(1) 1.12, p= \\
0.289\end{array}$ \\
\hline
\end{tabular}

Source: Primary data collected 2017/18, author's own calculation. Notes: Y (temporality) discrete-count variable on ego-level, reporting median and interquartile range as non-parametric measures. Differences in groups tested using k-sample equality of median test, values equal to the dropped for comparison, Pearson's $\chi 2$ corrected for continuity, significance levels: ${ }^{*} p<0.10,{ }^{* *} p<0.05,{ }^{* * *} p<0.01$

Second, as displayed in Table 6.4, non-white elderly individuals depict significantly larger personal networks than white elderly individuals. The median number of connections amount to 27 for non-white as opposed to 18 for white egos. This might be related to the general care obligations that elderly non-white individuals take on within families, e.g. sharing their pension income and taking care of their grandchildren (Du Toit and Neves 2009; Subbarao 1999). 


\section{Table 6.4 Age composition across ethnic identity groups}

\begin{tabular}{|c|c|c|c|c|c|}
\hline \multirow{2}{*}{$\begin{array}{l}\text { Composition across } \\
\text { personal networks }\end{array}$} & \multicolumn{2}{|c|}{ white $(n=40)$} & \multicolumn{2}{|c|}{ non-white $(n=165)$} & \multirow{2}{*}{$\begin{array}{l}\text { Equality of } \\
\text { median }\end{array}$} \\
\hline & Median & IQR & Median & IQR & \\
\hline \multicolumn{6}{|l|}{ Age - Ego } \\
\hline Young Adults & 22 & 15 & 28 & 13 & $\begin{array}{l}\chi^{2}(1) 0.00 \\
p=1.000\end{array}$ \\
\hline $\begin{array}{l}\text { Lower Middle-aged } \\
\text { Adults }\end{array}$ & 18 & 14 & 25 & 12 & $\begin{array}{l}\chi^{2}(1) 0.00 \\
p=0.930\end{array}$ \\
\hline $\begin{array}{l}\text { Upper Middle-aged } \\
\text { Adults }\end{array}$ & 17.5 & 16 & 28 & 11 & $\begin{array}{l}\chi^{2}(1) 0.13 \\
p=0.717\end{array}$ \\
\hline Older Aged Adults & 25 & 19 & 23 & 16 & $\begin{array}{l}\chi^{2}(1) 0.00 \\
p=1.000\end{array}$ \\
\hline Elderly & $27^{\star \star}$ & 36 & $18^{* *}$ & 13.5 & $\begin{array}{l}\chi 2(1) 4.23 \\
p=0.026\end{array}$ \\
\hline
\end{tabular}

Support edge with

minor

Source: Primary data collected 2017/18, author's own calculation. Notes: Y (degree) discrete-count variable on ego-level, reporting median and interquartile range as non-parametric measures. Differences in groups tested using k-sample equality of median test, values equal to the dropped for comparison, Pearson's $\chi 2$ corrected for continuity, significance levels: ${ }^{*} p<0.10,{ }^{* *} p<0.05,{ }^{* * *} p<0.01$

Third, and this also encompasses the fourth difference, concerns age similarity between egos and their alters, as shown in Table 6.5. Both non-white young adults and non-white lower-middle aged adults have comparatively fewer links to other age cohorts compared to their white peers (external links only exceeding internal links by 19 per cent versus 53 per cent and 50 per cent versus 63 per cent respectively). 


\section{Table 6.5 Ego-Alter similarity across ethnic identity groups}

\begin{tabular}{|c|c|c|c|c|}
\hline \multirow{3}{*}{$\begin{array}{l}\text { Indicators (same versus } \\
\text { different group) }\end{array}$} & \multicolumn{4}{|c|}{ Ego-Alter similarity (dyads) } \\
\hline & \multicolumn{2}{|c|}{ white ( $\mathrm{N}=40)$} & \multicolumn{2}{|c|}{ non-white $(\mathrm{N}=165)$} \\
\hline & Mean & SE & Mean & SE \\
\hline Young Adults & $.53^{\star \star}$ & .129 & $.19^{\star \star}$ & .064 \\
\hline Lower Middle-aged Adults $\mathrm{EI}_{\mathrm{I}}$ & $.69^{*}$ & .069 & $.50^{\star}$ & .054 \\
\hline Upper Middle-aged Adults $\mathrm{EI}_{\mathrm{E}}$ & .73 & .045 & .73 & .036 \\
\hline Older Aged Adults & .87 & .042 & .80 & .033 \\
\hline ElderlyEI & .65 & .073 & .72 & .043 \\
\hline No Education ${ }_{E I}$ & . & - & .12 & . \\
\hline Primary Education $_{\mathrm{EI}}$ & . & . & .31 & . \\
\hline Second. Education $_{\mathrm{EI}}$ & .29 & .168 & .31 & .055 \\
\hline Tertiary Education ${ }_{\mathrm{EI}}$ & $-.03^{\star \star \star}$ & .081 & $.29^{\star \star \star}$ & .045 \\
\hline Income source labour & $-.01^{* \star \star}$ & .068 & $.20^{\star \star \star}$ & .037 \\
\hline Unemployed $_{\mathrm{EI}}$ & . & . & .40 & . \\
\hline Not in labour force $\mathrm{EI}_{\mathrm{I}}$ & $.57^{*}$ & .079 & $.28^{*}$ & .056 \\
\hline
\end{tabular}

Source: Primary data collected 2017/18, author's own calculation. Notes: Differences in groups tested using two-sample t-tests, El scores (continuous) computed on ego-level per personal network. Significance levels: ${ }^{*} p<0.10,{ }^{* *} p<0.05,{ }^{* * *} p<0.01$

More precisely, a white young adult's support activities are mostly with alters from different age cohorts. Although non-white young adults are linked to other age cohorts, in comparison they have more links with peers than white young adults. This might be owing to more inter-generational support among cousins and a wider family network. I further tested if the average number of minors reported in personal networks varies across non-white and white ethnic identities and it emerged that non-white egos report significantly more, namely 4.5 support activities with minors, compared with white egos with only 1.3.

Fifth, as also shown in Table 6.5, educational similarity between an ego and alters with tertiary degrees diverges across ethnic identity groupings. White egos holding a tertiary degree are slightly more likely to be linked to others with tertiary degrees (internal links exceed external by 3 per cent). The opposite holds true for non-white ethnic identity egos. Hereby, the number of external links (different degree) exceeds internal links (same degree) by 29 per cent. With tertiary being the highest level of education, it thus implies that non-white tertiary degree holders have more ties (on average 32 per cent) with lower degree levels than white egos. The same pattern holds true for individuals' labour status: non-white egos show more links to individuals who have no income source via labour (21 per cent more external links compared to white egos). 


\section{Differing motives and intentions: support temporality}

Using the initial findings stemming from network measures allows me to set the scope for a more in-depth exploration of differences across ethnic identities, drawing on motives and intentions as reflected in personal statements of egos. More specifically, I explore the latter through differences across white and nonwhite identities in relation to the temporality of support. This thus represents one entry points to discuss personal motives and intentions.

\subsection{Regular support activities}

Regular support was more common in network compositions of non-white than white ethnic identities. 'Regular' refers to support happening on a daily, weekly or monthly basis. Generally, while some activities seemed to be almost nondistinguishable from 'how one passes their days', others are more distinct practices playing a particular role in one's life. Regular practices represent actions that are embedded in an individual's daily life and reality. They capture to some extent - how one spends time, with whom, where and within which social and physical spaces individuals spend a vast share of their daily lives. Particularly for non-white egos, support activities constituted a more substantial share of reported activities than for white egos. Before detailing further, this might indicate that 'support' includes short-term gestures, necessities and need for non-white egos. In the following, I describe two themes that emerged when engaging with the meaning reflected in qualitative statements, which I configured as habits and arrangements. I considered the pairing of relationship types (e.g. mother, friend, grandmother) and places (domestic, work, leisure) with mentioned notions of positive emotions (love, care, respect, etc.), necessity (problem, bills, struggles, etc.) and dependency (have to, choice, need to). The following section describes what defines and distinguishes them based on a pairing of personal motives and intentions.

\subsubsection{Habits}

Habits are generally so embedded in an individual's life that respondents often struggled to answer why support activities take place and what motivates them to engage in respective activities. It appears that there is a deeply embedded understanding related to 'what one does' and thus to support practices that have been - to some extent - normalised through a collective, or widely accepted, understanding, common sense practice or general expectations. These habits were particularly found to be associated with marriage, nuclear family bonds and 
parental care. Often, intentions and motives reflected nothing other than the stated social bond one has with the respected person, such as 'because she is my wife', 'family', 'being a parent' as well as references to shared spaces such as 'it is my parents' house' or simply, 'I do not think I need to be motivated to care for my very own daughter' (ego\#82_nw_m_587). They tend to reflect positive feelings and emotions such as love, encouragement, respect and caring. Some acknowledge these feelings as functional for someone else's wellbeing, for instance 'if a kid doesn't get help and love from a parent, then they become bad' (ego\#77_nw_f_51). There is also a sense of companionship, e.g. 'to be together and it is just on my own free will' (ego\#75_nw_f_69). Thus 'habits' do not seem to be associated with necessities in the pragmatic sense. They fulfil certain functions for individuals but depict a lower link to the general necessities and material needs in life.

\subsubsection{Arrangements}

Arrangements on the other hand can be seen as support activities with a more explicit framework between two or more individuals. What distinguishes them from habits is a sense of more explicit dependency or shared benefits on either or both sides. Thereby the reason for dependency on the other can vary and can be different for both individuals within these arrangements. They are also more tied to general necessities such as 'living arrangements' or daily needs such as 'household assistance' or 'paying one's bills' but also mention general 'problems' or difficulties. In their function, they seem to respond to external challenges rather than 'fulfilling an internal bond', whereby the latter becomes the means to cope with challenges. For example, general difficulties with housing affordability in Windhoek caused individuals to share accommodation: 'We were not working when we came to Windhoek. So, we [cousins] decided to share a room to make life easier. We had to share and help each other' (ego\#83_nw_m_55).

Furthermore, within the domestic sphere this can also include fulfilling parental duties for children whose parents, for various reasons, are unable to take care of them: 'Some people simply bring their children and you cannot say no to a child given to you. You cannot stay in a house alone. [It is due to] poverty' (ego\#78_nw_m_51). Taking in children and giving them a place to live can also correspond to one's own needs, especially during old age, for example 'they are my eyes' (ego\#80_nw_m_70) or 'so that one day, they support me in the future' (ego\#193_nw_m_33). Apart from home as a place to live, these arrangements also include paying for water and electricity or food, as mentioned in the motives of respondents. However, they also exist in the professional sphere of individuals. Dependency in these arrangements becomes less a matter of 
catering for basic needs such as housing or general care and more a matter of membership. Partaking regularly in certain networks - on a daily basis and beyond - seems to determine access to information, contacts and employment more broadly:

It is like a Namibian thing. It is just sometimes you do need to know someone and then you help. That 'who knows who' principle. It is so broad - for all things like help, information, contacts. It is efficiency; helps to connect the right people with the right people. (ego\#116_w_f_32).

Access to potential (better) jobs is then - for some - not just associated with one's own but also other's benefits: 'we share employment information because we are still looking for promotions. If you get a better job, it is good for both of us' (ego\#114_nw_m_32). However, it is also beyond mutual benefit for some whereby having access to employment and being employed was also found to be associated with obligations: 'I am employed, and so I have to help her out. It is something I have to do' (ego\#130_nw_m_32). Conversely, regular arrangements such as the passing of information and contacts also gain importance in the absence of employment: 'I tell my sister about the jobs every time because she is unemployed, and I want her to get a job' (ego\#52_nw_f_25).

However, external challenges and a sense of (mutual) obligation seem to resonate more in the personal statements of non-white as opposed to white egos. Habits and their deeply ingrained embedding in social relationships do not differ much per se. Marriage and parental obligations, feelings of love, care, respect and encouragement were found in both groups. This is not to say that individuals' understandings of these dynamics do not differ within groups. They certainly reflect different notions, roles and understandings dependent on the individual herself.

However, a cross-group difference is less apparent than when looking at arrangements. Arrangements for white egos seem to depict a more pragmatic sense of 'best solutions' given the circumstances, whereas circumstances do not depict 'challenges of poverty' or 'inabilities to cater for a basic need'. For example, when talking about a shared accommodation arrangement, statements show a notion of 'the natural thing to do', 'choice' or 'temporal solution':

It is very convenient for her and cheaper than her own accommodation. It is nice to have her. It is more her need than mine, she makes the choice. It is for her to decide whether she wants to be there or not. It will be OK if she wants to move out; it is nice to have her but [she] must move out at some point. (ego\#42_w_f_65).

This pragmatic sense of 'best solution' seems to be more strongly paired to obligation and necessity as well as to implicit dependency for non-white egos. The phrasing 'have to help', 'no choice' and the acknowledgement of hardship 
such as 'needing to find a job', 'needing a place to stay' or 'needing to help out' is more prevalent. Whereas implicit dependency is based on a sense of want for white egos - 'it is a reciprocal situation. It is not something that is ever abused. We want to help each other; it is just easier' (ego\#105_w_f_25) - for non-white egos, it is more a sense of need: 'I have to help her; she is unemployed and has a child to support' (ego\#68_nw_m_35); 'They are my family. I have no choice. I have to help them' (ego\#73_nw_m_63); or 'I am employed, and I have to help her out. It is something I have to do' (ego\#130_nw_m_32). This hints towards the aspect mentioned in the Black Tax narrative that personal support for non-white Namibians corresponds to structural deficiencies in the economic context.

Moreover, there are comparably fewer explicit references made to a potential expectation to fulfil collective standards reflected in 'one's culture' in the personal statements of white egos. However, non-white egos do mention such as in 'it is in my culture to do so' (ego\#54_nw_m_42) or 'it is culture, this is how we have always functioned. You help, they must help you back' (ego\#68_nw_m_35). These notions especially hint towards more broadly accepted understandings and practices but also a certain pressure to fulfil them in order to remain part of these reciprocal systems. These observations speak to the Black Tax narrative; particularly the obligations to help those who have helped you on the way, or not saying no to those who raised you (Busani-Dube 2019). Within different or similar contexts, associated practices have been previously coined as swapping (Stack 2003), not leaving others behind (F. Stewart 2016) or reciprocity on demand (Schnegg 2015) regarding non-white community dynamics.

Comparatively stronger obligations might further correspond to greater shortterm needs, leading to higher engagement in regular support activity for nonwhite egos. 


\section{Thinking beyond - considerations regarding informal social protection}

This research represents a first explorative engagement with personal support networks regarding their general composition, motives, and intentions. I paid attention to markers mentioned in the Black Tax narrative as well as to associated literature. In this paper, I set a focus on similarity and temporality in support interactions. A broader aim was depicting differences in meaning-making of support activities - within personal networks and broader social identity groups to revisit understandings of ISP. The Black Tax narrative allowed me to introduce the lens of structural inequalities to debates on ISP as well as a focus on the experiences of support among members of the extended family. How such has altered an understanding of policy-based framings of ISP shall be described below.

In sum, network compositions differed across non-white and white ethnic identities in a few aspects and some differences were more interpretable than others. First, is the greater regularity of support activities observed in non-white as opposed to white egos and the larger networks of elderly non-white egos. Second, differences also included more peer-to-peer support for higher education levels and having income via labour for white egos. Third, non-white egos holding these higher positions were more associated with support towards lower situated alters (education) or unemployed alters as well as those who are not in the labour force. This also resembles the claim of Black Tax, whereby having studied or having a job requires taking care of those who did not study or are unemployed.

These entry points allowed for an exploration of different notions in motives and intentions. The breadth of meaning in motives and intentions of support is remarkable. Though certainly these statements only provide a glimpse into broader stories, they reflect some of the notions and prevailing ideas of egos. Most notably, non-white egos' personal motives and intentions depicted a stronger sense of necessity, dependency and responding to external challenges such as unemployment, poverty, lack of capability to cater for basic needs and similar conditions related to poverty or being comparatively worse off in economic terms.

Conceptually, an exploration of personal motives and intentions also revealed that support categorisation can overlook important distinctions across an individual's socioeconomic realities and social positions: the obstacles and 
circumstances they face, the opportunities they have or foresee for someone, as well as how they make sense of, tackle or utilise them.

Returning to understandings of ISP, this research makes the following arguments. This concerns aspects which might not be underexplored but generally overlooked. One of them is the aspect of compatibility of informal behaviour with formalised standards. Another one is the aspect of accounting for group-based inequality in studies on ISP.

\subsection{The compatibility aspect of the 'informal'}

While it has been acknowledged that informal practices constitute a vital aspect of individuals' welfare in the global South, these practices are not necessarily understood as a 'way of life', or deeply embedded 'social understanding' of living together. Further, in describing social practices that existed prior to or in spite of economic and political systems as 'informal' also comes with a sense of suspending them from a 'status quo' within a given context and portrays them as an 'inferior alternative'.

Doing so suggests a premise that first, there is a formal space - the economic and political system. Only then, there are social practices that respond to or shall be aligned with formal systems. If one wants to understand social practices between individuals without their compatibility in yielding certain outcomes, it seems that one also needs to retreat from modern societies and delve into anthropological studies on traditional societies and their social and economic dynamics.

The compatibility framing thus overlooks the aspect that 'informal' practices are vital parts of the daily lives of individuals. They are often so embedded in one's life that it is hard for individuals to assign an explicit rationale to them. They are a mode of togetherness; spending one's life and days together. However, as much as they might merit different principles, they do not remain 'immune' to their economic surroundings - particularly so in unequal contexts. As shown in my findings, they respond to external challenges and therefore reflect certain dependencies and necessities for some but not others. Particularly among nonwhite ethnic identity groups, social practices reflect a sense of need, necessity, dependency as well as obligation and responsibility, whereby one cannot live well while others suffer. For example, this was shown in statements that referred to support for others 'who can hardly afford to buy food for themselves', but also in statements which reflect the 'weight of support' e.g. 'I was the one taking care of everyone. My brother worked but was not there for my mother. When my sister started working, she relieved the weight off my shoulders' (ego\#18_nw_m_31). External challenges often revolve around not being able to provide for basic needs as well as the lack of employment and thus financial resources. In this way, support practices do respond to economic systems and 
this might be a reason why aspects such as consumption smoothing, risk sharing, or poverty and inequality reduction can indeed be understood when looking at these practices. However, responding to external challenges does something to the individuals involved: a sense of responsibility or obligation might have had seemingly neutral cultural roots, as described in Mhlongo's book as traditional, African way of life, communal life, family upliftment, or family responsibility (Mhlongo et al. 2019). I found the sense of tradition in my findings as well, for example 'because [of] old tradition. We have a belief that if we do something for older people, you shall be blessed in return. I used to do that for blessings' (ego\#15_nw_m_46); or 'as a child, by tradition it is a must that we help our parents. For their sacrifice. They helped me finish school' (ego\#68_nw_m_35).

What used to be a lifecycle dynamic, or general family caretaking, might have become changed and aggravated by external economic circumstances. While a practice such as 'you cannot say no to elders who formerly raised you' (BusaniDube 2019), or the above-mentioned blessings might have been a 'seemingly neutral' cultural tradition, inequality seems to operationalise those traditions and change the nature of relationships for groups facing systemic inequalities. Thereby, 'cannot say no' might not just come from one's cultural upbringing and corresponding social norms and values anymore. It can also stem from an acknowledgement that if one says no, the economic wellbeing of others might be affected, worsened or threatened. Knowing that historic inequality created unequal starting positions for some, the scope to 'say no' can be harder for those who are now better off but socially linked to lower positions, whereas economic consequences of 'saying no' are also harder to endure for those in lower positions. This dynamic has been previously observed among black individuals in other economic contexts (P. Stewart 2015; Stack 2003) as well as in this research.

Further, one could argue that the way in which economic disadvantage has given rise to greater feelings of obligation and responsibility for non-white individuals, it might have done the opposite for white individuals: economic advantage may have shifted their relationships to being more individualised. For instance, statements of white egos carried less of a community 'sense' or 'tradition', and expectations towards younger generations to 'become contributors to the family' featured less strongly. It is that very dissonance and change in relationships that needs to be understood further as both a consequence and cause of continued lived inequality. It is also the socially embedded foundation of practices that needs acknowledgement as it indicates a choice of lifestyle, togetherness, but also a certain persistence of informal support despite 'formal' efforts to replace, adapt or change them. 
I would further argue that these dissonances between the 'social' and the 'economic' is not a unique phenomenon but might apply to other identity groups whose values, social norms and corresponding collective behaviours do not necessarily complement existing global and national economic rationales particularly within unequal, post-colonial contexts. A notion of labelling lifestyles and their social practices as 'informal' further indicates and reinforces a power imbalance between two existing systems, which I will further address in the following section.

\subsection{Support as a function of necessity}

This section speaks to the aspect that within the global South, support practices among individuals often remain understood within the realm of 'poverty' or 'marginalised groups'. While this is not to say that these studies do not provide valuable insights, my research has demonstrated that support practices exist beyond 'spaces of necessity' and looking beyond the space of poverty can reveal differing degrees of necessity in support relationships.

Indeed, studies in various contexts reflect an underlying assumption that the type and patterns of support practices can be observed as they take place among a poor community (Stack 2003) or within a rural and marginalised community (Tvedten and Nangulah 1999; Tvedten 2011; Schnegg 2015). Yet, they rarely explore whether these or similar dynamics exist beyond these spaces. Patterns of reciprocity over time or on demand get interpreted against the hardships and resulting necessities that poverty and marginalisation bring forward. Yet, my study demonstrated that necessities change but continue to exist for individuals who would be considered as 'non-poor' in economic terms. Black Tax further suggests that better situated non-white individuals support individuals who fare worse economically. Interestingly, this points to the fact that an individual does not need to be exposed to economic hardships and resulting necessities themselves. Understanding the necessity to support across socioeconomic positions and within the space of personal networks and relationships can indirectly link 'better off' individuals through social relationships to necessities formerly understood within the space of poverty. By focusing on practices among poor individuals, it can overlook more 'vertical support' from non-poor to poor.

What is interesting and linked to the aspect of relationships, is that in studies on Namibia, one can also find a discussion of conceptualisations of households, kinship and families as economic and social units cooperating with each other. Debates show that household boundaries can be more fluid (Greiner 2012; $2011 ; 2010)$, and families are founded as a web of present, past and continued relationships among individuals, resulting in different care obligations and mutual responsibilities (Ruiz-Casares 2010; Kalomo et al. 2018). When moving beyond the space of poverty - whether tied to certain communities, neighbourhoods or 
rural locations, those varying conceptualisations of households, kinship and families do not feature as strongly. It almost seems that within modern, urbanised spaces there prevails an assumption that individuals adapt to the most prominent economic, nuclear family model. It is noteworthy that discussions on rural and urban support dynamics do acknowledge a blended understanding of households and families proposing alternative models, such as multi-local households, emphasising a relational and trans-local perspective (Greiner 2012). Interestingly, there often remains a filter of (multi-dimensional, though) poverty when acknowledging these alternatives. Doing so adversely seems to associate different economic organisations and social structures of households and families with poverty, which seems to be not just reflected in research but also in public stereotypes about social groups being situated among the lower ranks of inequality - as shown in section 7.4 in the statements of white individuals talking about non-white individuals' sharing practices or ways of living more broadly.

However, calling life models and social organisation a function of necessity, or their circumstances more broadly, neglects the fact that these can indeed be a norm or normality. They might have been operationalised and respond to their economic circumstances, as discussed in the section above, which generally makes it hard to see what would exist in spite of poverty or inequality. More broadly, the portrayal of alternatives then further demonstrates a general notion of ranked parallel systems. Imbalanced shares of power in shaping the economic system for social groups and individuals are equally reflected in viewing alternative models of households and families as a function of poverty and inequality. There then appears to be little room for just viewing them as alternatives per se. This comes full circle with the 'informality' argument, whereas alternatives that differ from 'standard economic systems' are placed into the 'adaptive or prevailing social space'. While some social spaces are more aligned and compatible with economic systems, others seem to become 'less powerful' derivatives of fixed systems with the option to assimilate rather than bend systems to accommodate social dynamics - not just in social policy design (for example, see Bevan 2004; G. D. Wood 2004) but economic systems more broadly. 


\section{Conclusion}

The Black Tax narrative is one example which illustrates how socio-political context matters and thereby contests scholarly framings and understandings of 'informal' or collective behaviours. My findings indicate how support practices respond to economic markets. Accounting for horizontal inequality draws out distinct markers in social, economic and political systems that disadvantage one group but not others (F. Stewart 2005). This applies to many markers, including age, gender, ethnic identity, race, or origin more broadly (UNDP 2015). However, these horizontal inequalities are often identified and defined by cross-group markers in that they acknowledge boundaries and inter-group separation by notions of discrimination, marginalisation, exclusion or differentiated access (for a discussion on social exclusion and chronic poverty, see for example Hickey and du Toit 2013).

In this regard, inequality becomes understood as a consequence of being part of or being associated with a certain social group whereby mainly inter- and not intra-group behaviour gives rise to inequalities. In other words, horizontal inequality is often viewed through discrimination against but not necessarily among the discriminated, whereby intersectional approaches then distinguish different degrees of discrimination across combinations of social identities (for example, see Brannon, Higginbotham, and Henderson 2017 for a discussion of class and race). I do not claim that inter-group interactions do not matter - they certainly do in explaining horizontal inequalities and apartheid is a prime example for the pertinence of this perspective. Moreover, cross-group behaviours can create unequal systems. However, there are also certain dynamics that arise within the compartmentalisation of systems that in turn might reinforce unequal systems.

In conclusion, this research provides an initial step to exploring ISP beyond a policy lens. It does so in a highly unequal society, namely Namibia. This exploration and the data informing this research does not come without limitations. As I draw on personal networks and thus detailed information on local environments of individuals, I do not know how personal networks are embedded in broader societal structures ${ }^{8}$. Additional sources and information on wider structures would enable further explorations, for example who are central actors, who links otherwise loosely connected social groups, or who inhibits support activities.

8 Sociometric data captures all the existing social connections of a social space. In empirical data collection, obtaining such is often not feasible as connections increase exponentially the more individuals are included in a population of interest. 


\section{Annexe 1}

\section{Table A1 Overview of the criteria considered when selecting the six ethnic identity groups included in this research}

\begin{tabular}{|c|c|c|c|}
\hline \multirow[b]{2}{*}{$\begin{array}{l}\text { Ethnic identity } \\
\text { group }\end{array}$} & \multicolumn{3}{|l|}{ Criteria } \\
\hline & $\begin{array}{l}\text { Settlement \& } \\
\text { population } \\
\text { share }\end{array}$ & $\begin{array}{l}\text { General cultural } \\
\text { background }\end{array}$ & $\begin{array}{l}\text { Socioeconomic } \\
\text { marginalisation }\end{array}$ \\
\hline Ovambo & $\begin{array}{l}\text { Since 16th } \\
\text { century } \\
46.7 \% \text { of } \\
\text { population }\end{array}$ & $\begin{array}{l}\text { Comprising } \\
\text { several tribes as } \\
\text { part of the Bantu } \\
\text { group }\end{array}$ & $\begin{array}{l}7.8 \% / 5.6 \% \text { in } \\
1 \text { st/10th Income } \\
\text { Decile }\end{array}$ \\
\hline Herero & $\begin{array}{l}\text { Since 16th } \\
\text { century } \\
9.1 \% \text { of } \\
\text { population }\end{array}$ & $\begin{array}{l}\text { From East Africa } \\
\text { Pastoral cattle- } \\
\text { breeding people }\end{array}$ & $\begin{array}{l}8.8 \% / 6.9 \% \text { in } \\
1 \text { st/10th Income } \\
\text { Decile }\end{array}$ \\
\hline German & $\begin{array}{l}\text { 1884, main influx } \\
\text { of settlers } 1903 \\
\text { onwards } \\
0.8 \% \text { of } \\
\text { population }\end{array}$ & $\begin{array}{l}\text { Western cultural } \\
\text { origin }\end{array}$ & $\begin{array}{l}0.0 \% / 86.6 \% \text { in } \\
1 \mathrm{st} / 10 \text { th Income } \\
\text { Decile }\end{array}$ \\
\hline Afrikaans & $\begin{array}{l}\text { 1915, South } \\
\text { Africa } \\
\text { colonisation } \\
9.3 \% \text { of } \\
\text { population }\end{array}$ & $\begin{array}{l}\text { Western cultural } \\
\text { origin }\end{array}$ & $\begin{array}{l}3.8 \% / 38.1 \% \text { in } \\
1 \text { st } / 10 \text { th Income } \\
\text { Decile }\end{array}$ \\
\hline Caprivi & $\begin{array}{l}\text { Multiple tribes } \\
\text { inhabiting the } \\
\text { Caprivi Strip } \\
4.9 \% \text { of } \\
\text { population }\end{array}$ & $\begin{array}{l}\text { Settlers in the } \\
\text { northern region of } \\
\text { today's Namibia }\end{array}$ & $\begin{array}{l}21.8 \% / 3.9 \% \text { in } \\
1 \text { st/10th Income } \\
\text { Decile }\end{array}$ \\
\hline Nama/Damara & $\begin{array}{l}\text { Relatives of the } \\
\text { Khoikhoi group } \\
12.4 \% \text { of } \\
\text { population }\end{array}$ & $\begin{array}{l}\text { Settlers in } \\
\text { southern region } \\
\text { of today's } \\
\text { Namibia }\end{array}$ & $\begin{array}{l}17.0 \% / 3.5 \% \text { in } \\
1 \text { st/10th Income } \\
\text { Decile }\end{array}$ \\
\hline
\end{tabular}

Notes: Quantitative indicators based on the Namibian Household Income and Expenditure Survey 2015/16. 


\section{Annexe 2}

\section{Table A2 Analytical steps applied for analysing regular support activities}

\begin{tabular}{|c|c|c|c|c|}
\hline $\begin{array}{l}\text { Familiarisation } \\
\text { \& network } \\
\text { composition }\end{array}$ & $\begin{array}{l}\text { Selection } \\
\text { criteria }\end{array}$ & $\begin{array}{l}\text { Coding - } \\
\text { emergent } \\
\text { themes }\end{array}$ & $\begin{array}{l}\text { Coding - } \\
\text { generated } \\
\text { themes }\end{array}$ & $\begin{array}{l}\text { Reviewed } \\
\text { and defined } \\
\text { themes }\end{array}$ \\
\hline \multirow[t]{3}{*}{$\begin{array}{l}\text { Regular } \\
\text { support more } \\
\text { common in } \\
\text { personal } \\
\text { support } \\
\text { networks of } \\
\text { non-white } \\
\text { individuals }\end{array}$} & \multirow[t]{3}{*}{$\begin{array}{l}\text { Frequency } \\
\text { of support } \\
\text { activity } \\
\text { ranging } \\
\text { from daily } \\
\text { to } \\
\text { monthly; } \\
\text { provided } \\
\text { activities }\end{array}$} & $\begin{array}{l}\text { Place: } \\
\text { domestic, work, } \\
\text { leisure }\end{array}$ & $\begin{array}{l}\text { Domestic, } \\
\text { relationship } \\
\text { nuclear and } \\
\text { marriage, } \\
\text { positive } \\
\text { emotions } \\
\text { dominant }\end{array}$ & $\begin{array}{l}\text { Habits - } \\
\text { deeply } \\
\text { embedded in } \\
\text { relationship, } \\
\text { collective } \\
\text { understanding, } \\
\text { unquestioned } \\
\text { practice }\end{array}$ \\
\hline & & $\begin{array}{l}\text { Relationship } \\
\text { nuclear and } \\
\text { marriage: } \\
\text { parents, } \\
\text { daughter, sister, } \\
\text { son, child, wife, } \\
\text { husband }\end{array}$ & $\begin{array}{l}\text { Domestic, } \\
\text { relationship } \\
\text { nuclear and } \\
\text { marriage, } \\
\text { necessity } \\
\text { and } \\
\text { dependency } \\
\text { dominant }\end{array}$ & $\begin{array}{l}\text { Arrangements } \\
\text { - less } \\
\text { embedded in } \\
\text { relationships, } \\
\text { relationship } \\
\text { more } \\
\text { functional, } \\
\text { responding to } \\
\text { external } \\
\text { circumstances, } \\
\text { mutual benefit } \\
\text { and/or } \\
\text { obligation }\end{array}$ \\
\hline & & $\begin{array}{l}\text { Positive } \\
\text { emotions: } \\
\text { love, care, } \\
\text { respect, } \\
\text { encouragement, } \\
\text { togetherness, } \\
\text { community }\end{array}$ & $\begin{array}{l}\text { Work, } \\
\text { positive } \\
\text { emotions } \\
\text { dominant }\end{array}$ & $\begin{array}{l}\text { Habits (as } \\
\text { described } \\
\text { above, less } \\
\text { commonly } \\
\text { observed) }\end{array}$ \\
\hline
\end{tabular}




\section{Table A2 (cont'd).}

\begin{tabular}{|c|c|c|c|c|}
\hline $\begin{array}{l}\text { Familiarisation } \\
\text { \& network } \\
\text { composition }\end{array}$ & $\begin{array}{l}\text { Selection } \\
\text { criteria }\end{array}$ & $\begin{array}{l}\text { Coding - } \\
\text { emergent } \\
\text { themes }\end{array}$ & $\begin{array}{l}\text { Coding - } \\
\text { generated } \\
\text { themes }\end{array}$ & $\begin{array}{l}\text { Reviewed } \\
\text { and defined } \\
\text { themes }\end{array}$ \\
\hline \multirow[t]{3}{*}{$\begin{array}{l}\text { Regular } \\
\text { support more } \\
\text { common in } \\
\text { personal } \\
\text { support } \\
\text { networks of } \\
\text { non-white } \\
\text { individuals }\end{array}$} & \multirow[t]{3}{*}{$\begin{array}{l}\text { Frequency } \\
\text { of support } \\
\text { activity } \\
\text { ranging } \\
\text { from daily } \\
\text { to } \\
\text { monthly; } \\
\text { provided } \\
\text { activities }\end{array}$} & $\begin{array}{l}\text { Necessity: } \\
\text { problem, } \\
\text { affordability, } \\
\text { unemployed, } \\
\text { not working, } \\
\text { bills, help, } \\
\text { poverty, } \\
\text { struggles }\end{array}$ & $\begin{array}{l}\text { Work, } \\
\text { necessity } \\
\text { and } \\
\text { dependency } \\
\text { dominant }\end{array}$ & $\begin{array}{l}\text { Arrangements } \\
\text { (as described } \\
\text { above, more } \\
\text { commonly } \\
\text { observed) }\end{array}$ \\
\hline & & \multirow{2}{*}{$\begin{array}{l}\text { Dependency: } \\
\text { have to, choice, } \\
\text { need to, must, } \\
\text { want to, cannot, } \\
\text { reciprocal, } \\
\text { abandon, return }\end{array}$} & $\begin{array}{l}\text { Leisure, } \\
\text { positive } \\
\text { emotions } \\
\text { dominant }\end{array}$ & $\begin{array}{l}\text { Habits (as } \\
\text { described } \\
\text { above, only } \\
\text { few } \\
\text { observations) }\end{array}$ \\
\hline & & & $\begin{array}{l}\text { Leisure, } \\
\text { necessity } \\
\text { and } \\
\text { dependency } \\
\text { dominant }\end{array}$ & $\begin{array}{l}\text { Arrangements } \\
\text { (as described } \\
\text { above, only } \\
\text { few } \\
\text { observations) }\end{array}$ \\
\hline
\end{tabular}

Notes: Based on primary data collected in 2017/18. Focussing in support activities and related statements on motivations and intentions of support marked as regular (daily, weekly, monthly) support. 


\section{References}

Arnall, A.; Furtado, J.; Ghazoul, J. and de Swardt, C. (2004) 'Perceptions of Informal Safety Nets: A Case Study from a South African Informal Settlement'. Development Southern Africa 21.3: 443-60 (accessed 22 October 2020)

Bevan, P. (2004) 'Conceptualising In/Security Regimes', in I. Gough and G.D. Wood (eds.) Insecurity and Welfare Regimes in Asia, Africa and Latin America, Cambridge: Cambridge University Press (accessed 22 October 2020)

Bond, J.E. (2011) 'Culture, Dissent, and the State: The Example of Commonwealth African Marriage Law', Yale Human Rights and Development Law Journal 14: 1 (accessed 22 October 2020)

Brannon, T.N.; Higginbotham, G.D. and Henderson, K. (2017) 'Class Advantages and Disadvantages Are Not so Black and White: Intersectionality Impacts Rank and Selves', Current Opinion in Psychology 18: 117-22 (accessed 22 October 2020)

Braun, V. and Clarke, V. (2012) 'Thematic Analysis', in H. Cooper, P.M. Camic, D.L. Long, A.T. Panter, D. Rindskopf and K.J. Sher (eds.), APA Handbook of Research Methods in Psychology, Vol. 2. Research Designs: Quantitative, Qualitative, Neuropsychological, and Biological, Washington, D.C.: American Psychological Association

Busani-Dube, D. (2019) 'Black Tax - What You Give up and What You Gain', in N. Mhlongo (ed), Black Tax: Burden or Ubuntu?, Johannesburg: Jonathan Ball Publishers

Calder, R. and Tanhchareun, T. (2014) Informal Social Protection: Social Relations and Cash Transfers, Barton: Australian Government, Department of Foreign Affairs and Trade

Clarke, V. and Braun, V. (2017) 'Thematic Analysis', The Journal of Positive Psychology 12.3: 297-98 (accessed 22 October 2020)

Cox, D. and Fafchamps, M. (2007) 'Extended Family and Kinship Networks: Economic Insights and Evolutionary Directions', in T.P. Schultz and J.A. Strauss (eds.), Handbook of Development Economics, London: Elsevier (accessed 22 October 2020)

Crossley, N.; Bellotti, E.; Edwards, G.; Everett, M.G.; Koskinen, J. and Tranmer, M. (2015) Social Network Analysis for Ego-Nets, London: SAGE Publications Ltd.

Devereux, S. (1999) 'Making Less Last Longer: Informal Safety Nets in Malawi', IDS Discussion Paper 373, Brighton: IDS

Di Falco, S. (2013) 'The Impact of Kinship Networks on the Adoption of Risk-Mitigating Strategies in Ethiopia'. World Development 43 (March): 100-110 (accessed 23 October 2020)

, and Erwin Bulte. (2011) 'A Dark Side of Social Capital? Kinship, Consumption, and Savings'. Journal of Development Studies 47.8: 1128-51 (accessed 23 October 2020).

Du Toit, A, and Neve, D. (2009) 'Trading on a Grant: Integrating Formal and Informal Social Protection in Post-Apartheid Migrant Networks'. Brooks World Poverty Institute Working Paper Series 7509. BWPI, The University of Manchester (accessed 23 October 2020)

Frayne, B. (2004) 'Migration and Urban Survival Strategies in Windhoek, Namibia'. Geoforum 35.4: 489-505 (accessed 23 October 2020)

(2001) 'Survival of the Poorest: Food Security and Migration in Namibia'. Ph.D., Canada: Queen's University (Canada) (accessed 23 October 2020)

Gough, I. (2013) 'Social Policy Regimes in the Developing World'. In A Handbook of Comparative Social Policy, edited by Patricia Kennett, 205-24. Cheltenham UK: Edward Elgar Publishing Ltd (accessed 23 October 2020)

Greiner, C. (2012) 'Can Households Be Multilocal? Conceptual and Methodological Considerations Based on a Namibian Case Study'. DIE ERDE - Journal of the Geographical Society of Berlin 143.3: 195-212 (accessed 23 October 2020) 
(2010) 'Patterns of Translocality: Migration, Livelihoods and Identities in Northwest Namibia'. Sociologus 60.2: 131-61 (accessed 23 October 2020)

Heemskerk, M.; Norton, A. and de Dehn, L. (2004) 'Does Public Welfare Crowd Out Informal Safety Nets? Ethnographic Evidence from Rural Latin America'. World Development 32.6: 941-55 (accessed 23 October 2020)

Hickey, S, and du Toit, A. (2013) 'Adverse Incorporation, Social Exclusion, and Chronic Poverty'. In Chronic Poverty: Concepts, Causes and Policy, edited by Andrew Shepherd and Julia Brunt, 134-59. Rethinking International Development Series. London: Palgrave Macmillan UK (accessed 23 October 2020)

Hoff, K. and Sen, A. (2005) 'The Kin System as a Poverty Trap?' SSRN Scholarly Paper ID 719141. Rochester, NY: Social Science Research Network (accessed 23 October 2020)

Ioannides, Y.M. and Datcher Loury, L. (2004) 'Job Information Networks, Neighborhood Effects, and Inequality'. Journal of Economic Literature 42.4: 1056-93 (accessed 23 October 2020)

Kalomo, E.N. (2018) 'Associations between HIV-Related Stigma, Self-Esteem, Social Support, and Depressive Symptoms in Namibia'. Aging \& Mental Health 22.12: 1570-1576 (accessed 23 October 2020)

Kalomo, E.N; Kyoung H.L.; Lightfoot, E and Freeman, R. (2018) 'Resilience among Older Caregivers in Rural Namibia: The Role of Financial Status, Social Support and Health'. Journal of Gerontological Social Work 61.6: 605-622 (accessed 23 October 2020)

Khumalo, F. (2019) 'An Inevitable Growing Pain'. In Black Tax: Burden or Ubuntu?, edited by Niq Mhlongo. Johannesburg: Jonathan Ball Publishers.

Krackhardt, D. and Stern, R. (1988) 'Informal Networks and Organizational Crises: An Experimental Simulation'. Social Psychology Quarterly 51.2: 123-40 (accessed 23 October 2020)

Laferrere, A. and Wolff, F-C. (2006) 'Microeconomic Models of Family Transfers'. In Handbook of the Economics of Giving, Altruism and Reciprocity, 81. Kolm: Elsevier.

Lin, N. (2002) Social Capital: A Theory of Social Structure and Action. Structural Analysis in the Social Sciences 19. Cambridge, UK; New York: Cambridge University Press.

Magubane, N.N. (2017) 'Black Tax: The Emerging Middle Class Reality'. Mini Dissertation, University of Pretoria (accessed 23 October 2020)

Mangoma, A., and Wilson-Prangley, A. (2019) 'Black Tax: Understanding the Financial Transfers of the Emerging Black Middle Class'. Development Southern Africa 36.4: 443-60 (accessed 23 October 2020)

McDonald, C.A.; Schiller, C. and Ueda, K. (1999) 'Income Distribution, Informal Safety Nets, and Social Expenditures in Uganda'. St. Louis, United States: Federal Reserve Bank of St Louis (accessed 23 October 2020)

Melber, H. (2005) 'Land and Politics in Namibia', Review of African Political Economy 32.103: 135-142.

Mhlongo, N. (2019) 'Keeping Our Ancestral Spirit of Ubuntu Alive', In Black Tax: Burden or Ubuntu? Johannesburg: Jonathan Ball Publishers.

Mhlongo, N.; Phehello Mofokeng, J.; Busani-Dube, D.; Mrwebi, P.; Khumalo, F; Chauke, C; Mncube, B.; and Sithole, L. (2019) Black Tax: Burden or Ubuntu? Johannesburg: Jonathan Ball Publishers.

Mncube, B. (2019) 'Black Tax and the Art of Investing', In Black Tax: Burden or Ubuntu? Johannesburg: Jonathan Ball Publishers.

Mofokeng, J.P. (2019) 'Andizi! Black Tax Is a Flawed Social Construct', In Black Tax: Burden or Ubuntu? Johannesburg: Jonathan Ball Publishers.

Mtolo, V. (2018) 'Living with "Black Tax"”, News24. 19 March 2018 (accessed 23 October 2020)

Mushaandja, J. (2015) 'The Burden of Black Tax', The Namibian. 2015 (accessed 23 October 2020)

Namibia Statistics Agency. (2017) ‘Namibia Household Income and Expenditure Survey', no. 2015/16 Report.

Namibia Statistics Agency, and World Bank. (2017) Does Fiscal Policy Benefit the Poor and Reduce Inequality in Namibia? World Bank (accessed 23 October 2020)

Ndinga-Kanga, M. (2019) 'Towards an Understanding of "Black Tax" and the Black Missing Middle', Daily Maverick. 2019 (accessed 23 October 2020) 
Newman, M. (2010) Networks: An Introduction. Oxford, New York: Oxford University Press.

Oduro, A.D. (2010) 'Formal and Informal Social Protection in Sub-Saharan Africa'. Background Paper for the European Report on Development (accessed 23 October 2020)

Pearson, J.E. (1986) 'The Definition and Measurement of Social Support'. Journal of Counseling \& Development 64.6: 390-95 (accessed 23 October 2020)

Perry, B.L.; Pescosolido, B.A. and Borgatti, S.P. 2018. Egocentric Network Analysis Foundations, Methods, and Models. New York: Cambridge University Press.

Ruiz-Casares, M. (2010) 'Kin and Youths in the Social Networks of Youth-Headed Households in Namibia'. Journal of Marriage and Family 72.5: 1408-25 (accessed 23 October 2020)

Sarason, I.G. and Sarason, B.R.. (2009) 'Social Support: Mapping the Construct'. Journal of Social and Personal Relationships 26.1: 113-120 (accessed 23 October 2020)

Schnegg, M. (2015). 'Reciprocity on Demand'. Human Nature 26.3: 313-30 (accessed 23 October 2020) Simmel, G. (1955). Conflict: The Web of Group-Affiliations. Free Press.

Sithole, L. (2019) ‘Beyond the Obligation'. In Black Tax: Burden or Ubuntu? Johannesburg: Jonathan Ball Publishers.

Stack, C.B. (2003) All Our Kin: Strategies for Survival in a Black Community. Repr. New York, NY: Basic Books.

Stewart, F. (2005) 'Horizontal Inequalities: A Neglected Dimension of Development'. In Wider Perspectives on Global Development, 101-35. Studies in Development Economics and Policy. Hampshire: Palgrave Macmillan UK

Stewart, F. (2016) 'Changing Perspectives on Inequality and Development'. Studies in Comparative International Development; New York 51.1: 60-80 (accessed 23 October 2020)

(2005) 'Horizontal Inequalities: A Neglected Dimension of Development'. In Wider Perspectives on Global Development, 101-35. Studies in Development Economics and Policy. Hampshire: Palgrave Macmillan UK

Stewart, P. (2015) 'You Moved Up, Did You Forget Us?: The Influence of African American IntraFamilial Social Mobility on Extended Family Relationships'. Journal of African American Studies 19.2: 214-32 (accessed 23 October 2020)

Subbarao, K. (1999) Namibia's Social Safety Net: Issues and Options for Reform. Policy Research Working Papers, no. WPS 1996. Washington, DC: The World Bank (accessed 23 October 2020)

Tvedten, I. (2011) 'As Long as They Don't Bury Me Here': Social Relations of Poverty in Namibian Shantytown. Basel Namibia Studies Series 11. Basel: Basler Afrika Bibliographien (accessed 23 October 2020)

Tvedten, I. and Nangulah, S. (1999) 'Social Relations of Poverty: A Case-Study from Owambo, Namibia'. CMI Report R 1999:5 (accessed 23 October 2020)

UNDP. (2015) 'Sustainable Development Goals'. UNDP. 2015 (accessed 23 October 2020)

Werger, C. (2009) 'Kinship Networks, Wealth and Economic Behaviour in Rural Ethiopia: Does Family Come at a Cost?', Thesis Development Economics: Wageningen University (accessed 27 October 2020)

Wood, G. D. (2004) Informal Security Regimes: Social Policy and the Search for a Secure Institutional Landscape, in Insecurity and Welfare Regimes in Asia, Africa and Latin America: Social Policy in Development Contexts, Cambridge, UK: Cambridge University Press.

Wood, G. and Gough, I. (2006) 'A Comparative Welfare Regime Approach to Global Social Policy'. World Development 34 (10): 1696-1712. Elsevier.

World Bank. (2017) ‘GINI Index’ (World Bank Estimate) | Data. (accessed 27 October 2020). 


\section{(2) institute of development \\ studies}

Delivering world-class research, learning and teaching that transforms the knowledge, action and leadership needed for more equitable and sustainable development globally.

Institute of Development Studies

Library Road

Brighton, BN1 9RE

United Kingdom

+44 (0)1273606261

ids.ac.uk

Charity Registration Number 306371

Charitable Company Number 877338

(C) Institute of Development Studies 2020 